\title{
Complex controls on nitrous oxide flux across a large-elevation gradient in the tropical Peruvian Andes
}

\author{
Torsten Diem $^{1, a}$, Nicholas J. Morley ${ }^{1}$, Adan Julian Ccahuana Quispe ${ }^{2}$, Lidia Priscila Huaraca Quispe ${ }^{2}$, \\ Elizabeth M. Baggs ${ }^{3}$, Patrick Meir ${ }^{4,5}$, Mark I. A. Richards ${ }^{1}$, Pete Smith ${ }^{1}$, and Yit Arn Teh ${ }^{1, a}$ \\ ${ }^{1}$ School of Biological Sciences, University of Aberdeen, Aberdeen, UK \\ ${ }^{2}$ Universidad Nacional de San Antonio Abad del Cusco, Cusco, Peru \\ ${ }^{3}$ The Royal (Dick) School of Veterinary Studies, University of Edinburgh, UK \\ ${ }^{4}$ School of GeoSciences, University of Edinburgh, Edinburgh, UK \\ ${ }^{5}$ Research School of Biology, Australian National University, Canberra, Canberra, Australia \\ a formerly at: the School of Geography and Geosciences, University of St Andrews, St Andrews, UK
}

Correspondence to: Yit Arn Teh (yateh@abdn.ac.uk)

Received: 23 March 2017 - Discussion started: 30 March 2017

Revised: 19 September 2017 - Accepted: 19 September 2017 - Published: 15 November 2017

\begin{abstract}
Current bottom-up process models suggest that montane tropical ecosystems are weak atmospheric sources of $\mathrm{N}_{2} \mathrm{O}$, although recent empirical studies from the southern Peruvian Andes have challenged this idea. Here we report $\mathrm{N}_{2} \mathrm{O}$ flux from combined field and laboratory experiments that investigated the process-based controls on $\mathrm{N}_{2} \mathrm{O}$ flux from montane ecosystems across a large-elevation gradient (600-3700 ma.s.1.) in the southern Peruvian Andes. Nitrous oxide flux and environmental variables were quantified in four major habitats (premontane forest, lower montane forest, upper montane forest and montane grassland) at monthly intervals over a 30-month period from January 2011 to June 2013. The role of soil moisture content in regulating $\mathrm{N}_{2} \mathrm{O}$ flux was investigated through a manipulative, laboratory-based ${ }^{15} \mathrm{~N}$-tracer experiment. The role of substrate availability (labile organic matter, $\mathrm{NO}_{3}^{-}$) in regulating $\mathrm{N}_{2} \mathrm{O}$ flux was examined through a fieldbased litter-fall manipulation experiment and a laboratorybased ${ }^{15} \mathrm{~N}-\mathrm{NO}_{3}^{-}$addition study, respectively. Ecosystems in this region were net atmospheric sources of $\mathrm{N}_{2} \mathrm{O}$, with an unweighted mean flux of $0.27 \pm 0.07 \mathrm{mg} \mathrm{N}-\mathrm{N}_{2} \mathrm{O} \mathrm{m}^{-2} \mathrm{~d}^{-1}$. Weighted extrapolations, which accounted for differences in land surface area among habitats and variations in flux between seasons, predicted a mean annual flux of $1.27 \pm 0.33 \mathrm{~kg} \mathrm{~N}_{2} \mathrm{O}-\mathrm{Nha}^{-1} \mathrm{yr}^{-1}$. Nitrous oxide flux was greatest from premontane forest, with an unweighted mean flux of $0.75 \pm 0.18 \mathrm{mg} \mathrm{N}-\mathrm{N}_{2} \mathrm{O} \mathrm{m}^{-2} \mathrm{~d}^{-1}$, translating to a
\end{abstract}

weighted annual flux of $0.66 \pm 0.16 \mathrm{~kg} \mathrm{~N}_{2} \mathrm{O}-\mathrm{N} \mathrm{ha}^{-1} \mathrm{yr}^{-1}$. In contrast, $\mathrm{N}_{2} \mathrm{O}$ flux was significantly lower in other habitats. The unweighted mean fluxes for lower montane forest, montane grasslands, and upper montane forest were $0.46 \pm 0.24 \mathrm{mg} \mathrm{N}-\mathrm{N}_{2} \mathrm{O} \mathrm{m}^{-2} \mathrm{~d}^{-1}, \quad 0.07 \pm 0.08 \mathrm{mg} \mathrm{N}-$ $\mathrm{N}_{2} \mathrm{O} \mathrm{m}^{-2} \mathrm{~d}^{-1}$, and $0.04 \pm 0.07 \mathrm{mg} \mathrm{N}_{-} \mathrm{N}_{2} \mathrm{O} \mathrm{m}^{-2} \mathrm{~d}^{-1}$, respectively. This corresponds to weighted annual fluxes of $\quad 0.52 \pm 0.27 \mathrm{~kg} \mathrm{~N}_{2} \mathrm{O}-\mathrm{N} \mathrm{ha}^{-1} \mathrm{yr}^{-1}, \quad 0.05 \pm 0.06 \mathrm{~kg} \mathrm{~N}_{2} \mathrm{O}$ $\mathrm{Nha}^{-1} \mathrm{yr}^{-1}$, and $0.04 \pm 0.07 \mathrm{~kg} \mathrm{~N}_{2} \mathrm{O}-\mathrm{N} \mathrm{ha}^{-1} \mathrm{yr}^{-1}$, respectively. Nitrous oxide flux showed weak seasonal variation across the region; only lower montane forest showed significantly higher $\mathrm{N}_{2} \mathrm{O}$ flux during the dry season compared to wet season. Manipulation of soil moisture content in the laboratory indicated that $\mathrm{N}_{2} \mathrm{O}$ flux was significantly influenced by changes in water-filled pore space (WFPS). The relationship between $\mathrm{N}_{2} \mathrm{O}$ flux and WFPS was complex and nonlinear, diverging from theoretical predictions of how WFPS relates to $\mathrm{N}_{2} \mathrm{O}$ flux. Nitrification made a negligible contribution to $\mathrm{N}_{2} \mathrm{O}$ flux, irrespective of soil moisture content, indicating that nitrate reduction was the dominant source of $\mathrm{N}_{2} \mathrm{O}$. Analysis of the pooled data indicated that $\mathrm{N}_{2} \mathrm{O}$ flux was greatest at 90 and $50 \%$ WFPS, and lowest at 70 and $30 \%$ WFPS. This trend in $\mathrm{N}_{2} \mathrm{O}$ flux suggests a complex relationship between WFPS and nitrate-reducing processes (i.e. denitrification, dissimilatory nitrate reduction to ammonium). Changes in labile organic matter inputs, through the manipulation of leaf litter-fall, did not alter $\mathrm{N}_{2} \mathrm{O}$ flux. Com- 
prehensive analysis of field and laboratory data demonstrated that variations in $\mathrm{NO}_{3}^{-}$availability strongly constrained $\mathrm{N}_{2} \mathrm{O}$ flux. Habitat - a proxy for $\mathrm{NO}_{3}^{-}$availability under field conditions - was the best predictor for $\mathrm{N}_{2} \mathrm{O}$ flux, with $\mathrm{N}$-rich habitats (premontane forest, lower montane forest) showing significantly higher $\mathrm{N}_{2} \mathrm{O}$ flux than $\mathrm{N}$-poor habitats (upper montane forest, montane grassland). Yet, $\mathrm{N}_{2} \mathrm{O}$ flux did not respond to short-term changes in $\mathrm{NO}_{3}^{-}$concentration.

\section{Introduction}

The tropics are the largest source of atmospheric nitrous oxide $\left(\mathrm{N}_{2} \mathrm{O}\right)$, accounting for at least half of all global $\mathrm{N}_{2} \mathrm{O}$ emissions (Hirsch et al., 2006; Huang et al., 2008; Kort et al., 2011; Nevison et al., 2007; Saikawa et al., 2014). The bulk of tropical $\mathrm{N}_{2} \mathrm{O}$ emissions come from terrestrial sources, with the largest emissions arising from agricultural land and unmanaged lowland tropical forests (Hirsch et al., 2006; Huang et al., 2008; Kort et al., 2011; Nevison et al., 2007; Saikawa et al., 2014). However, while we have a relatively robust understanding of the global atmospheric budget as a whole (Hirsch et al., 2006; Huang et al., 2008; Saikawa et al., 2014), our knowledge of regional atmospheric budgets, particularly at the sub-continental scale, is much more limited, due to the constraints imposed by the spatial distribution of existing atmospheric sampling networks and ground-based, ecosystemscale sampling efforts (Kort et al., 2011; Nevison et al., 2004, 2007; Saikawa et al., 2014).

In order to predict and model $\mathrm{N}_{2} \mathrm{O}$ flux at these smaller (sub-continental) spatial scales, bottom-up emissions inventories or process-based models are often used, with emissions estimates constrained by empirical measurements (Werner et al., 2007; Li et al., 2000; Potter et al., 1996; Saikawa et al., 2013). However, these models are only as reliable as the data used to parameterize them; as a consequence, ecosystems that are under-represented in the empirical literature or which are poorly understood may be modelled less accurately, with knock-on effects for larger-scale emissions estimates (Saikawa et al., 2013; Teh et al., 2014; Werner et al., 2007). Nitrous oxide dynamics in montane tropical ecosystems are particularly poorly understood, because past research has concentrated on $\mathrm{N}_{2} \mathrm{O}$ flux from lowland tierra firme forests (Saikawa et al., 2013; Teh et al., 2014; Werner et al., 2007). Montane ecosystems, however, are important components of many tropical landscapes, and account for a sizeable land area. For example, in continental South America, montane ecosystems (> $500 \mathrm{ma.s.1}$.) cover more than $8 \%$ of the land surface (Eva et al., 2004), and play key roles in regional carbon $(\mathrm{C})$, nitrogen $(\mathrm{N})$, and greenhouse gas (GHG) dynamics (Girardin et al., 2010; Moser et al., 2011; Teh et al., 2014; Wolf et al., 2012, 2011). Processbased models predict that $\mathrm{N}_{2} \mathrm{O}$ fluxes from these montane environments are lower than those from the lowland tropics (i.e.
$<1.0 \mathrm{~kg} \mathrm{~N}_{2} \mathrm{O}-\mathrm{N} \mathrm{ha}^{-1} \mathrm{yr}^{-1}$ ) (Saikawa et al., 2013; Werner et al., 2007). However, these models have rarely been tested against empirical data, and several field studies indicate that $\mathrm{N}_{2} \mathrm{O}$ flux from montane ecosystems can exceed these prior models' estimates (Corre et al., 2010; Teh et al., 2014; Veldkamp et al., 2008). In some instances, $\mathrm{N}_{2} \mathrm{O}$ flux from montane ecosystems can in fact approach emissions from lowland forests, begging the question as to whether or not existing models do, in fact, accurately represent flux from these highelevation ecosystems (Corre et al., 2010; Teh et al., 2014; Veldkamp et al., 2008).

In order to improve our wider understanding of the dynamics and biogeochemistry of $\mathrm{N}_{2} \mathrm{O}$ in montane tropical forests, we conducted a combined field and laboratory study to investigate the environmental controls on denitrification and $\mathrm{N}_{2} \mathrm{O}$ flux across a large-elevation gradient (600-3700 m a.s.1.) in the tropical Peruvian Andes. Prior work from this region indicated that montane ecosystems in this area were stronger sources of $\mathrm{N}_{2} \mathrm{O}$ than predicted by bottom-up process models (Teh et al., 2014). In particular, lower-elevation premontane and lower montane forests, which account for the majority of the land area in this region $(\sim 54 \%)$, showed emission rates that are on par with lowland tropical forests, suggesting that these ecosystems could be important contributors to regional atmospheric budgets (Teh et al., 2014). Nitrous oxide flux appeared to be derived from nitrate reduction (i.e. denitrification, dissimilatory nitrate reduction to ammonium), and was linked to seasonal variations in climate, with $\mathrm{N}_{2} \mathrm{O}$ emissions increasing during the dry season compared to the wet season (Teh et al., 2014). However, contrary to theoretical expectations (Davidson, 1991; Firestone and Davidson, 1989; Groffman et al., 2009; Davidson and Verchot, 2000), $\mathrm{N}_{2} \mathrm{O}$ flux was not directly correlated with soil moisture content in our field dataset (Teh et al., 2014), raising unresolved questions about the role of seasonal variations in soil moisture content in driving $\mathrm{N}_{2} \mathrm{O}$ flux. We hypothesized that the weak relationship between $\mathrm{N}_{2} \mathrm{O}$ flux and soil moisture content was because soil water-filled pore space (WFPS) - an index of soil moisture and a proxy for soil anaerobiosis normally fell above the theoretical threshold where $\mathrm{N}_{2} \mathrm{O}$ flux was constrained by the availability of anaerobic microsites (i.e. $\sim 60 \%$ WFPS) in our preliminary dataset (Davidson, 1991; Firestone and Davidson, 1989; Groffman et al., 2009; Davidson and Verchot, 2000; Teh et al., 2014). Even during the dry season, WFPS rarely fell below this threshold value (Teh et al., 2014), allowing other driving variables, such as nitrate $\left(\mathrm{NO}_{3}^{-}\right)$, to play a more dominant role in regulating $\mathrm{N}_{2} \mathrm{O}$ flux (Teh et al., 2014).

In the work presented here, we extended our time series to multi-annual timescales, in order to better understand the role of longer-term climatic variability in modulating $\mathrm{N}_{2} \mathrm{O}$ flux. We also conducted a series of manipulative field and laboratory experiments to investigate the mechanistic controls on $\mathrm{N}_{2} \mathrm{O}$ flux in greater detail, and to test hypotheses raised by our earlier work (as described below) (Teh et al., 2014). 
Furthermore, these manipulative experiments were crucial in helping us interpret our time series of field observations, because prior research indicated that the relationship between individual control variables (e.g. WFPS or $\mathrm{NO}_{3}^{-}$) and $\mathrm{N}_{2} \mathrm{O}$ flux were confounded by the simultaneous action of multiple control variables (Teh et al., 2014). The overarching goals of this research were to investigate how climate and environmental variables regulate $\mathrm{N}_{2} \mathrm{O}$ flux over multi-annual timescales; clarify the role of soil moisture as a proximate or distal control on $\mathrm{N}_{2} \mathrm{O}$ flux; and evaluate the role of key substrates for nitrate reduction (i.e. labile organic matter, $\mathrm{NO}_{3}^{-}$) in driving $\mathrm{N}_{2} \mathrm{O}$ flux. Specifically, we hypothesized the following.

H1 Enhanced $\mathrm{N}_{2} \mathrm{O}$ flux during the dry season (i.e. during periods of reduced soil moisture) is due to an increase in $\mathrm{N}_{2} \mathrm{O}$ flux from nitrification and reduced $\mathrm{N}_{2} \mathrm{O}$ reduction during denitrification

H2 $\mathrm{N}_{2} \mathrm{O}$ flux is poorly correlated with soil water-filled pore space in situ because soil moisture content does not normally constrain denitrification under field conditions; however, $\mathrm{N}_{2} \mathrm{O}$ flux is closely correlated with waterfilled pore space when soil moisture content is more limiting for denitrification (i.e. $<60 \%$ WFPS)

$\mathrm{H3} \mathrm{N}_{2} \mathrm{O}$ flux increases proportionately with the availability of substrates for denitrification (i.e. $\mathrm{NO}_{3}^{-}$, labile organic matter).

In order to address these three objectives and their attendant hypotheses, we quantified $\mathrm{N}_{2} \mathrm{O}$ flux and environmental variables from four major habitat types (premontane forest, lower montane forest, upper montane forest and montane grassland) at monthly intervals over a 30 -month period. We also conducted manipulative laboratory experiments that investigated how variations in soil moisture content (WFPS) and $\mathrm{NO}_{3}^{-}$availability influenced $\mathrm{N}_{2} \mathrm{O}$ flux. In addition, we manipulated labile organic matter availability through a fieldbased litter-fall manipulation study, recognizing that labile organic matter plays an important role in supplying not only the reducing equivalents for nitrate reduction, but also indirectly providing inorganic $\mathrm{N}$ for ammonia oxidation and nitrate reduction via $\mathrm{N}$ mineralization (Morley and Baggs, 2010; Blackmer and Bremner, 1978; Davidson, 1991; Firestone et al., 1980; Weier et al., 1993).

\section{Materials and methods}

\subsection{Study site}

Measurements were conducted on the eastern slope of the Andes in the Kosñipata Valley, Manu National Park, Peru (Fig. 1) (Malhi et al., 2010). This $3.02 \times 10^{6}$ ha $\left(30200 \mathrm{~km}^{2}\right)$ region has been the subject of intensive ecological, biogeochemical and climatological studies since 2003 by the Andes
Biodiversity and Ecosystem Research Group (or, ABERG; $\mathrm{http}: / / \mathrm{www}$.andesconservation.org), and contains a series of long-term permanent plots across a $200-3700 \mathrm{~m}$ above sea level ( $m$ a.s.l) elevation gradient that stretches from the western Amazon to the Andes (Malhi et al., 2010). This part of the Andes experiences pronounced seasonality in rainfall but not in air temperature; the dry season extends from May to September and the wet season from October to April (Girardin et al., 2010). Thirteen sampling plots (approximately $20 \times 20 \mathrm{~m}$ each) were established at four different habitats across a gradient spanning $600-3700 \mathrm{~m}$ a.s.l., including premontane forest (600-1200 m a.s.l.; $n=3$ plots), lower montane forest (1200-2200 m a.s.l.; $n=3$ plots), upper montane forest (2200-3200 m a.s.l.; $n=3$ plots), and montane grasslands (3200-3700 m a.s.l.; $n=4$ plots; colloquially referred to as "puna") (Fig. 1). In premontane forest, sampling plots were established in Hacienda Villa Carmen, a 3065 ha biological reserve operated by the Amazon Conservation Association (ACA), containing a mixture of old-growth forest, secondary forest and agricultural plots (Teh et al., 2014). Sampling for soil gas flux was concentrated in the oldgrowth portions of the reserve. For lower montane and upper montane forests, sampling plots were established adjacent to or within existing 1 ha permanent sampling plots established by ABERG (Teh et al., 2014). Sampling plots were also established in montane grasslands (Teh et al., 2014). To capture a representative range of environmental conditions, mesotope-scale (100 m-1 km scale landforms) topographic features were sampled (Belyea and Baird, 2006). Mesotopic features include ridges, slopes, flats, and a high-elevation basin. The latter two landforms include wet, grassy lawns with no discernible grade, and a peat-filled depression, respectively. Summary site descriptions are provided in Table 1. Data on soil properties were collected as part of this study, while mean annual precipitation is from earlier research by ABERG (Girardin et al., 2010).

\subsection{Soil-atmosphere exchange}

Field sampling was performed over a 30-month period from January 2011 to June 2013 for all habitats except for premontane forest. Due to circumstances outside our control, only 24 months of data were collected for premontane forest, with sampling commencing in July 2011. Soil-atmosphere flux was collected monthly, except where flooding or landslides prevented safe access by investigators to the study sites. Gas exchange rates were determined with five replicate gas flux chambers deployed in each of the 13 plots $(n=65$ flux observations per month). All representative landforms were sampled in each habitat (Table 1).

Soil-atmosphere flux of $\mathrm{CH}_{4}, \mathrm{~N}_{2} \mathrm{O}$ and $\mathrm{CO}_{2}$ were determined using a static flux chamber approach (Livingston and Hutchinson, 1995), although only $\mathrm{N}_{2} \mathrm{O}$ flux is reported here. Methane and $\mathrm{CO}_{2}$ flux are discussed in detail in another publication (Jones et al., 2016). Static flux chamber measure- 


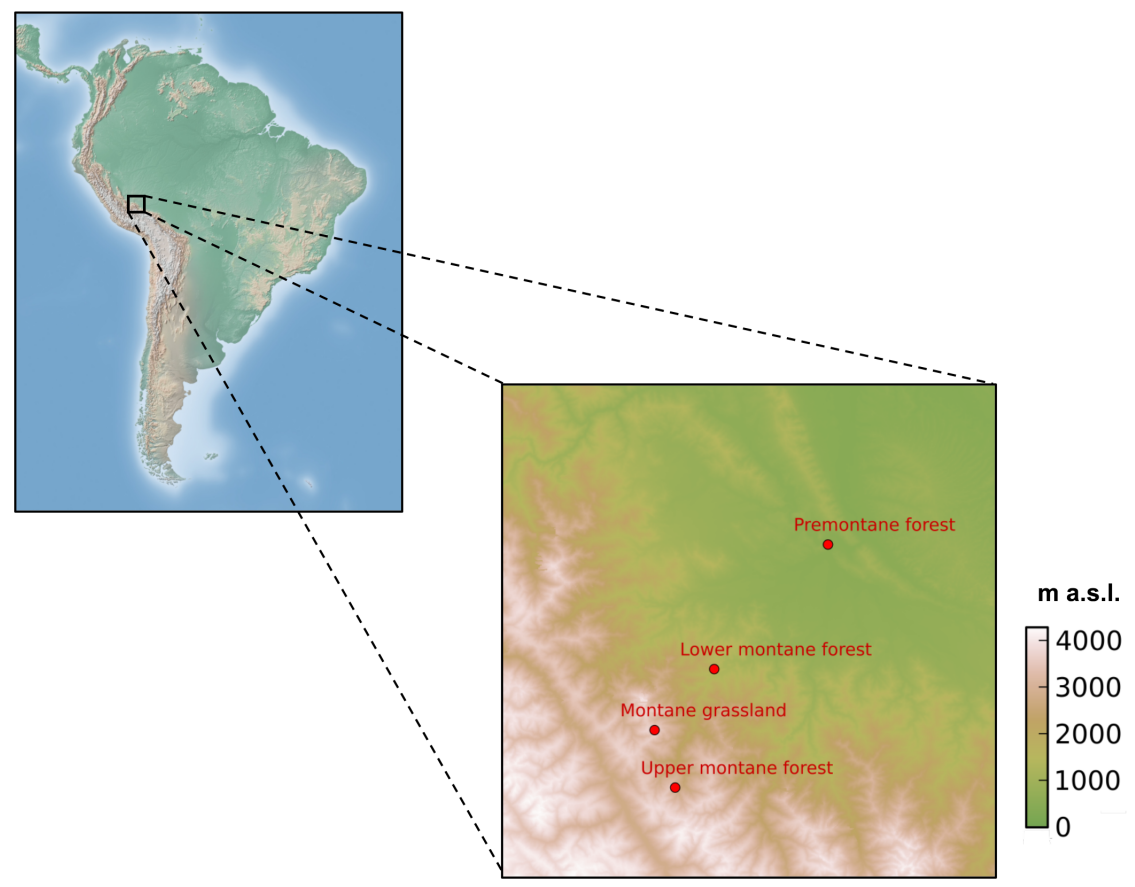

Figure 1. Map of study sites across the Kosñipata Valley, Manu National Park, Peru.

ments were made by enclosing a $0.03 \mathrm{~m}^{2}$ area with cylindrical, opaque (i.e. dark), two-component (i.e. base and lid) vented chambers with a $\sim 8 \mathrm{~L}$ volume. Chamber bases were permanently installed to a depth of approximately $5 \mathrm{~cm}$ and inserted $>1$ month prior to the commencement of sampling, in order to minimize potential artefacts from root mortality following base emplacement (Varner et al., 2003). Chamber lids were fitted with small computer case fans to promote even mixing in the chamber headspace (Pumpanen et al., 2004). Headspace samples were collected from each flux chamber over a $30 \mathrm{~min}$ enclosure period, with samples collected at four discrete intervals, $7.5 \mathrm{~min}$ apart, using a gastight syringe. Gas samples were stored in evacuated Exetainers ${ }^{\circledR}$ (Labco Ltd., Lampeter, UK), shipped to the UK by courier, and subsequently analysed for $\mathrm{CH}_{4}, \mathrm{~N}_{2} \mathrm{O}$ and $\mathrm{CO}_{2}$ concentrations with a Thermo TRACE GC Ultra (Thermo Fisher Scientific Inc., Waltham, Massachusetts, USA) at the University of St Andrews. Chromatographic separation was achieved using a Porapak-Q column, and analyte concentrations quantified using a flame ionization detector (FID) for $\mathrm{CH}_{4}$, electron capture detector (ECD) for $\mathrm{N}_{2} \mathrm{O}$, and methanizer-FID for $\mathrm{CO}_{2}$. Instrumental precision was determined by repeated analysis of standards and was better than $5 \%$ for all detectors. Gas flux rates were determined using the R HMR package to plot best-fit lines to the data for headspace concentration against time for individual flux chambers (Pedersen et al., 2010; R Team, 2012). Gas mixing ratios (ppm) were converted to areal flux by using the Ideal Gas Law to solve for the quantity of gas in the headspace (on a mole or mass basis), normalized by the surface area of each static flux chamber (Livingston and Hutchinson, 1995). Measurements resulting in zero net flux were included in our dataset.

\subsection{Environmental variables}

To investigate the effects of environmental variables on trace gas dynamics, we determined soil moisture, soil oxygen content in the $0-10 \mathrm{~cm}$ depth, soil temperature, and air temperature at the time of flux sampling. Volumetric soil moisture content was determined using portable soil moisture probes (ML2x ThetaProbe, Delta-T Device Ltd., Cambridge, UK) inserted into the substrate immediately adjacent to each flux chamber $(<5 \mathrm{~cm}$ from each chamber base; depth of 0 $10 \mathrm{~cm}$ ). Soil moisture content is reported here as water-filled pore space (WFPS), and is calculated using the measurements of volumetric water content and bulk density (Breuer et al., 2000). Soil $\mathrm{O}_{2}$ concentration was determined using the approach described by Teh et al. (2014). Soil temperature $(0-10 \mathrm{~cm}$ depth), chamber temperature and air temperature was determined using type $\mathrm{K}$ thermocouples (Omega Engineering Ltd., Manchester, UK). Data on aboveground litterfall, meteorological variables (i.e. photosynthetically active radiation, air temperature, relative humidity, rainfall, wind speed, wind direction), continuous plot-level soil moisture (10 and $30 \mathrm{~cm}$ depths) and soil temperature $(0,10,20$ and $30 \mathrm{~cm}$ depths) measurements were also collected, but are not reported in this publication. 


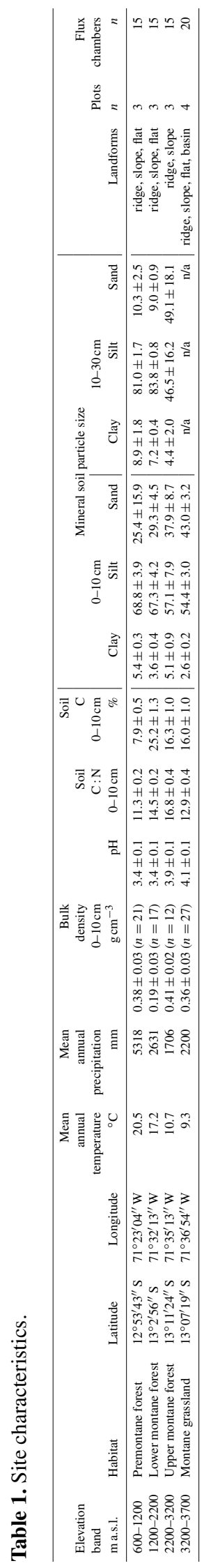

Resin-extractable inorganic $\mathrm{N}$ flux (i.e. ammonium, $\mathrm{NH}_{4}^{+}$; nitrate, $\mathrm{NO}_{3}^{-}$) were quantified in all plots using a resin bag approach (Templer et al., 2005; Subler et al., 1995). From August 2011 onwards, ion exchange resin bags $(n=15$ resin bags per elevation) were deployed in the plant rooting zone (i.e. $0-10 \mathrm{~cm}$ depth in premontane forest, lower montane forest and montane grasslands; $0-15 \mathrm{~cm}$ in upper montane forest), following established protocols (Templer et al., 2005; Subler et al., 1995). Samples were collected at monthly intervals (where possible) for determination of monthly, timeaveraged $\mathrm{NH}_{4}^{+}$and $\mathrm{NO}_{3}^{-}$flux (Subler et al., 1995). For some plots, this sampling frequency was periodically disrupted due to natural hazards (i.e. landslides, river flooding) preventing safe access to the study sites. Resin bags were shipped to the University of Aberdeen after collection from the field, inorganic $\mathrm{N}$ was extracted using $2 \mathrm{M} \mathrm{KCl}$ and concentrations determined colourimetrically using a Burkard SFA2 continuous-flow analyser (Burkard Scientific Ltd., Uxbridge, UK) (Templer et al., 2005; Subler et al., 1995).

\subsection{Water-filled pore space manipulation study}

We investigated the effects of WFPS on $\mathrm{N}_{2} \mathrm{O}$ flux derived from nitrate reduction or nitrification using a ${ }^{15} \mathrm{~N}$ tracer experiment. Soil cores for all habitats were collected from the $0-10 \mathrm{~cm}$ depth, and were not fully air-dried nor sieved prior to incubation. Soils were distributed into glass jars and adjusted to $10 \%$ below the target WFPS values of $30,50,70$ and $90 \%$, either by letting the soils partially air-dry or by adding water to them, depending on the WFPS of the soils at the time of collection ( $n=5$ for each ${ }^{15} \mathrm{~N}$ addition and 3 controls for each WFPS for a total of $n=212$; see Table 2). Additional de-ionized water, containing the ${ }^{15} \mathrm{~N}$ tracers, was subsequently added gravimetrically to raise WFPS to target levels. The exception to this was for the upper montane forest, where samples were collected from the $0-10 \mathrm{~cm}$ depth of the mineral soil, but not from the organic layer. The reason for this is that the mineral soil layer in the upper montane forest is overlain by a thick organic horizon up to $17 \mathrm{~cm}$ deep, consisting of poorly decomposed leaves, roots, and humic materials; very akin to low density peat (Zimmermann et al., 2012, 2009a, b). In contrast, the organic matter in the upper $10 \mathrm{~cm}$ soil layer in the other habitats is closely intermixed with the mineral phase, and does not normally constitute a distinct mineral-free horizon. Thus, to sample mineral soil in the upper montane forest, we had to sample beneath this thick organic horizon.

Two different types of ${ }^{15} \mathrm{~N}$ tracers (30 at. \%) were applied to the soils in order to determine the proportion of $\mathrm{N}_{2} \mathrm{O}$ derived from nitrate reduction and nitrification (Bateman and Baggs, 2005). ${ }^{14} \mathrm{~N}-\mathrm{NH}_{4}^{15} \mathrm{~N}-\mathrm{NO}_{3}$ was used to quantify the amount of $\mathrm{N}_{2} \mathrm{O}$ produced by nitrate reduction, while ${ }^{15} \mathrm{~N}-$ $\mathrm{NH}_{4}^{15} \mathrm{~N}-\mathrm{NO}_{3}$ was used to quantify the amount of $\mathrm{N}_{2} \mathrm{O}$ produced from both nitrate reduction and nitrification. The difference between the two was used to calculate the amount 
Table 2. Description of the water-filled pore space and $\mathrm{NO}_{3}^{-}$addition treatments for the laboratory manipulation experiments.

\begin{tabular}{|c|c|c|c|c|c|c|c|}
\hline \multirow[b]{2}{*}{ Habitat } & \multirow{2}{*}{$\begin{array}{l}\text { Experimental } \\
\text { treatment }\end{array}$} & \multirow[b]{2}{*}{ Soil depth } & \multirow[b]{2}{*}{ Soil type } & WFPS & \multicolumn{2}{|c|}{ Inorganic $\mathrm{N}$ added } & \multirow{2}{*}{$\begin{array}{r}\text { Replicate } \\
n\end{array}$} \\
\hline & & & & $\%$ & $\operatorname{ng~N}(\mathrm{g} \text { soil })^{-1}$ & ${ }^{15} \mathrm{~N}$ tracer & \\
\hline \multicolumn{8}{|l|}{ Water-filled pore space } \\
\hline \multirow[t]{8}{*}{ Premontane forest } & $90 \%$ WFPS & $0-10$ & mineral & 90 & 200 & ${ }^{15} \mathrm{NH}_{4}^{15} \mathrm{NO}_{3}$ & 5 \\
\hline & $90 \%$ WFPS & $0-10$ & mineral & 90 & 200 & ${ }^{14} \mathrm{NH}_{4}^{15} \mathrm{NO}_{3}$ & 5 \\
\hline & $70 \%$ WFPS & $0-10$ & mineral & 70 & 200 & ${ }^{15} \mathrm{NH}_{4}^{15} \mathrm{NO}_{3}$ & 5 \\
\hline & $70 \%$ WFPS & $0-10$ & mineral & 70 & 200 & ${ }^{14} \mathrm{NH}_{4}^{15} \mathrm{NO}_{3}$ & 5 \\
\hline & $50 \%$ WFPS & $0-10$ & mineral & 50 & 200 & ${ }^{15} \mathrm{NH}_{4}^{15} \mathrm{NO}_{3}$ & 5 \\
\hline & $50 \%$ WFPS & $0-10$ & mineral & 50 & 200 & ${ }^{14} \mathrm{NH}_{4}^{15} \mathrm{NO}_{3}$ & 5 \\
\hline & $30 \%$ WFPS & $0-10$ & mineral & 30 & 200 & ${ }^{15} \mathrm{NH}_{4}^{15} \mathrm{NO}_{3}$ & 5 \\
\hline & $30 \%$ WFPS & $0-10$ & mineral & 30 & 200 & ${ }^{14} \mathrm{NH}_{4}^{15} \mathrm{NO}_{3}$ & 5 \\
\hline \multirow[t]{8}{*}{ Lower montane forest } & $90 \%$ WFPS & $0-10$ & mineral & 90 & 200 & ${ }^{15} \mathrm{NH}_{4}^{15} \mathrm{NO}_{3}$ & 5 \\
\hline & $90 \%$ WFPS & $0-10$ & mineral & 90 & 200 & ${ }^{14} \mathrm{NH}_{4}^{45} \mathrm{NO}_{3}$ & 5 \\
\hline & $70 \%$ WFPS & $0-10$ & mineral & 70 & 200 & ${ }^{15} \mathrm{NH}_{4}^{15} \mathrm{NO}_{3}$ & 5 \\
\hline & $70 \%$ WFPS & $0-10$ & mineral & 70 & 200 & ${ }^{14} \mathrm{NH}_{4}^{15} \mathrm{NO}_{3}$ & 5 \\
\hline & $50 \%$ WFPS & $0-10$ & mineral & 50 & 200 & ${ }^{15} \mathrm{NH}_{4}^{15} \mathrm{NO}_{3}$ & 5 \\
\hline & $50 \%$ WFPS & $0-10$ & mineral & 50 & 200 & ${ }^{14} \mathrm{NH}_{4}^{15} \mathrm{NO}_{3}$ & 5 \\
\hline & $30 \%$ WFPS & $0-10$ & mineral & 30 & 200 & ${ }^{15} \mathrm{NH}_{4}^{45} \mathrm{NO}_{3}$ & 5 \\
\hline & $30 \%$ WFPS & $0-10$ & mineral & 30 & 200 & ${ }^{14} \mathrm{NH}_{4}^{15} \mathrm{NO}_{3}$ & 5 \\
\hline \multirow[t]{8}{*}{ Upper montane forest } & $90 \%$ WFPS & $10-20$ & mineral & 90 & 20 & ${ }^{15} \mathrm{NH}_{4}^{15} \mathrm{NO}_{3}$ & 5 \\
\hline & $90 \%$ WFPS & $10-20$ & mineral & 90 & 20 & ${ }^{14} \mathrm{NH}_{4}^{45} \mathrm{NO}_{3}$ & 5 \\
\hline & $70 \%$ WFPS & $10-20$ & mineral & 70 & 20 & ${ }^{15} \mathrm{NH}_{4}^{15} \mathrm{NO}_{3}$ & 5 \\
\hline & $70 \%$ WFPS & $10-20$ & mineral & 70 & 20 & ${ }^{14} \mathrm{NH}_{4}^{15} \mathrm{NO}_{3}$ & 5 \\
\hline & $50 \%$ WFPS & $10-20$ & mineral & 50 & 20 & ${ }^{15} \mathrm{NH}_{4}^{15} \mathrm{NO}_{3}$ & 5 \\
\hline & $50 \%$ WFPS & $10-20$ & mineral & 50 & 20 & ${ }^{14} \mathrm{NH}_{4}^{45} \mathrm{NO}_{3}$ & 5 \\
\hline & $30 \%$ WFPS & $10-20$ & mineral & 30 & 20 & ${ }^{15} \mathrm{NH}_{4}^{15} \mathrm{NO}_{3}$ & 5 \\
\hline & $30 \%$ WFPS & $10-20$ & mineral & 30 & 20 & ${ }^{14} \mathrm{NH}_{4}^{15} \mathrm{NO}_{3}$ & 5 \\
\hline \multirow[t]{8}{*}{ Montane grassland } & $90 \%$ WFPS & $0-10$ & mineral & 90 & 20 & ${ }^{15} \mathrm{NH}_{4}^{15} \mathrm{NO}_{3}$ & 5 \\
\hline & $90 \%$ WFPS & $0-10$ & mineral & 90 & 20 & ${ }^{14} \mathrm{NH}_{4}^{15} \mathrm{NO}_{3}$ & 5 \\
\hline & $70 \%$ WFPS & $0-10$ & mineral & 70 & 20 & ${ }^{15} \mathrm{NH}_{4}^{15} \mathrm{NO}_{3}$ & 5 \\
\hline & $70 \%$ WFPS & $0-10$ & mineral & 70 & 20 & ${ }^{14} \mathrm{NH}_{4}^{45} \mathrm{NO}_{3}$ & 5 \\
\hline & $50 \%$ WFPS & $0-10$ & mineral & 50 & 20 & ${ }^{15} \mathrm{NH}_{4}^{45} \mathrm{NO}_{3}$ & 5 \\
\hline & $50 \%$ WFPS & $0-10$ & mineral & 50 & 20 & ${ }^{14} \mathrm{NH}_{4}^{15} \mathrm{NO}_{3}$ & 5 \\
\hline & $30 \%$ WFPS & $0-10$ & mineral & 30 & 20 & ${ }^{15} \mathrm{NH}_{4}^{15} \mathrm{NO}_{3}$ & 5 \\
\hline & $30 \%$ WFPS & $0-10$ & mineral & 30 & 20 & ${ }^{14} \mathrm{NH}_{4}^{45} \mathrm{NO}_{3}$ & 5 \\
\hline \multicolumn{8}{|l|}{ Nitrate addition } \\
\hline \multirow[t]{4}{*}{ Premontane forest } & control & $0-10$ & mineral & 80 & $\mathrm{n} / \mathrm{a}$ & $\mathrm{n} / \mathrm{a}$ & 5 \\
\hline & $+50 \%$ background $\mathrm{NO}_{3}^{-}$ & $0-10$ & mineral & 80 & $780 \pm 60$ & $\mathrm{~K}^{15} \mathrm{NO}_{3}$ & 5 \\
\hline & $+100 \%$ background $\mathrm{NO}_{3}^{-}$ & $0-10$ & mineral & 80 & $1570 \pm 120$ & $\mathrm{~K}^{15} \mathrm{NO}_{3}$ & 5 \\
\hline & $+150 \%$ background $\mathrm{NO}_{3}^{-}$ & $0-10$ & mineral & 80 & $2350 \pm 170$ & $\mathrm{~K}^{15} \mathrm{NO}_{3}$ & 5 \\
\hline \multirow[t]{4}{*}{ Lower montane forest } & control & $0-10$ & mineral & 80 & $\mathrm{n} / \mathrm{a}$ & $\mathrm{n} / \mathrm{a}$ & 5 \\
\hline & $+50 \%$ background $\mathrm{NO}_{3}^{-}$ & $0-10$ & mineral & 80 & $700 \pm 60$ & $\mathrm{~K}^{15} \mathrm{NO}_{3}$ & 5 \\
\hline & $+100 \%$ background $\mathrm{NO}_{3}^{-}$ & $0-10$ & mineral & 80 & $1400 \pm 120$ & $\mathrm{~K}^{15} \mathrm{NO}_{3}$ & 5 \\
\hline & $+150 \%$ background $\mathrm{NO}_{3}^{-}$ & $0-10$ & mineral & 80 & $2100 \pm 180$ & $\mathrm{~K}^{15} \mathrm{NO}_{3}$ & 5 \\
\hline \multirow[t]{8}{*}{ Upper montane forest } & control & $0-10$ & organic & 80 & $\mathrm{n} / \mathrm{a}$ & $\mathrm{n} / \mathrm{a}$ & 5 \\
\hline & $+50 \%$ background $\mathrm{NO}_{3}^{-}$ & $0-10$ & organic & 80 & $90 \pm 20$ & $\mathrm{~K}^{15} \mathrm{NO}_{3}$ & 5 \\
\hline & $+100 \%$ background $\mathrm{NO}_{3}^{-}$ & $0-10$ & organic & 80 & $180 \pm 50$ & $\mathrm{~K}^{15} \mathrm{NO}_{3}$ & 5 \\
\hline & $+150 \%$ background $\mathrm{NO}_{3}^{-}$ & $0-10$ & organic & 80 & $270 \pm 70$ & $\mathrm{~K}^{15} \mathrm{NO}_{3}$ & 5 \\
\hline & control & $10-20$ & mineral & 80 & $\mathrm{n} / \mathrm{a}$ & $\mathrm{n} / \mathrm{a}$ & 5 \\
\hline & $+50 \%$ background $\mathrm{NO}_{3}^{-}$ & $10-20$ & mineral & 80 & $90 \pm 40$ & $\mathrm{~K}^{15} \mathrm{NO}_{3}$ & 5 \\
\hline & $+100 \%$ background $\mathrm{NO}_{3}^{-}$ & $10-20$ & mineral & 80 & $190 \pm 70$ & $\mathrm{~K}^{15} \mathrm{NO}_{3}$ & 5 \\
\hline & $+150 \%$ background $\mathrm{NO}_{3}^{-}$ & $10-20$ & mineral & 80 & $280 \pm 110$ & $\mathrm{~K}^{15} \mathrm{NO}_{3}$ & 5 \\
\hline \multirow[t]{4}{*}{ Montane grassland } & control & $0-10$ & mineral & 80 & $\mathrm{n} / \mathrm{a}$ & $\mathrm{n} / \mathrm{a}$ & 5 \\
\hline & $+50 \%$ background $\mathrm{NO}_{3}^{-}$ & $0-10$ & mineral & 80 & $30 \pm 10$ & $\mathrm{~K}^{15} \mathrm{NO}_{3}$ & 5 \\
\hline & $+100 \%$ background $\mathrm{NO}_{3}^{-}$ & $0-10$ & mineral & 80 & $60 \pm 20$ & $\mathrm{~K}^{15} \mathrm{NO}_{3}$ & 5 \\
\hline & $+150 \%$ background $\mathrm{NO}_{3}^{-}$ & $0-10$ & mineral & 80 & $90 \pm 40$ & $\mathrm{~K}^{15} \mathrm{NO}_{3}$ & 5 \\
\hline
\end{tabular}


of $\mathrm{N}_{2} \mathrm{O}$ derived from nitrification alone. After application of the tracers, the jars were sealed and gas samples taken at 0 , $6,12,24,36$, and $48 \mathrm{~h}$ to determine rates of gas flux. Nitrous oxide yield was calculated as the ratio ${ }^{15} \mathrm{~N}-\mathrm{N}_{2} \mathrm{O}$ flux : ${ }^{15} \mathrm{~N}-$ $\mathrm{N}_{2} \mathrm{O}$ flux $+{ }^{15} \mathrm{~N}-\mathrm{N}_{2}$ flux. Soils were sampled at the end of the experiment for $\mathrm{NO}_{3}^{-}$concentration, $\mathrm{NH}_{4}^{+}$concentration, and total $\mathrm{C}$ and $\mathrm{N}$ content.

Soil gas concentrations $\left(\mathrm{N}_{2} \mathrm{O}, \mathrm{CO}_{2}\right.$, and $\left.\mathrm{CH}_{4}\right)$ were measured on a GC as described in Sect. 4.2, while ${ }^{15} \mathrm{~N}-\mathrm{N}_{2}$ and ${ }^{15} \mathrm{~N}-\mathrm{N}_{2} \mathrm{O}$ were measured on a SerCon 20:20 isotope ratio mass spectrometer equipped with an ANCA TGII preconcentration module (SerCon Ltd., UK). The coefficient of variation $(\mathrm{CV}$; an index of instrumental precision) for repeated analysis of gas concentration and isotope standards was $<5 \%$. ${ }^{15} \mathrm{~N}-\mathrm{N}_{2} \mathrm{O}$ and ${ }^{15} \mathrm{~N}-\mathrm{N}_{2}$ fluxes were calculated from the ${ }^{15} \mathrm{~N}$ atom percent excess of the samples compared to the controls using the HMR package (Pedersen et al., 2010).

\subsection{Litter-fall manipulation experiments}

We conducted a field-based litter-fall manipulation experiment to test for the effects of variations in labile organic matter availability on trace gas flux. This study took place over a 14-month period (April 2012 to June 2013), and consisted of four experimental treatments (control, $+50 \%$ litter addition, $+100 \%$ litter addition, litter removal) implemented across three habitats (premontane forest, lower montane forest, upper montane forest), with six replicate plots per treatment per habitat (each treatment plot was $0.5 \times 0.5 \mathrm{~m}$ in size; $n=24$ observations per habitat; $n=72$ observations per sampling increment). Leaf litter addition rates for the +50 and $+100 \%$ litter addition treatments were determined based on prior research from this study site, and fell within the natural range of variability observed across this elevational gradient (Girardin et al., 2010).

Litter-fall for the litter addition treatments was collected monthly in litter baskets ( $n=3$ litter baskets per treatment plot for a total of $n=18$ per habitat). These data were also used to determine the background rates of leaf litter-fall among habitats. For the control, litter inputs simply reflected natural background litter-fall rates. For the +50 and $+100 \%$ litter addition treatments, background litter inputs were supplemented with additional litter taken from the litter baskets. Briefly, wet litter was weighed in the field using a portable scale, gently mixed (homogenized), and then re-distributed to the +50 and $+100 \%$ litter addition plots in amounts proportional to the average amount of wet litter that fell into the litter baskets over the course of the month. As a consequence, the amount of litter added in the two litter addition treatments was not fixed but varied according to the natural background rate of litter-fall. For the litter removal treatment, leaf litter was removed from the forest floor at the start of the experiment, and $3 \mathrm{~mm}$ nylon mesh was placed over the surface of the treatment plot to prevent further litter ingress to the soil surface. Any debris accumulating on the mesh was removed at monthly intervals.

Trace gas flux and environmental variables were determined at seven time points over the course of the 14-month experiment using the methods described in Sect. 4.2. In addition, soil moisture (WFPS from the $0-10 \mathrm{~cm}$ depth), soil temperature $(0-10 \mathrm{~cm}$ depth), air temperature, soil gas concentrations $\left(\mathrm{O}_{2}, \mathrm{CH}_{4}, \mathrm{~N}_{2} \mathrm{O}, \mathrm{CO}_{2}\right)$ from the 0-10 and $20-30 \mathrm{~cm}$ depths, litter $\mathrm{C}$, and litter $\mathrm{N}$ were determined concomitantly. Litter $\mathrm{C}$ and $\mathrm{N}$ content was determined on a Carlo-Erba NA 2500 elemental analyser (CE Instruments Ltd, Wigan, UK) at the University of Aberdeen.

\subsection{Nitrate addition experiment}

To quantify the effect of $\mathrm{NO}_{3}^{-}$availability on $\mathrm{N}_{2} \mathrm{O}$ flux, we conducted a ${ }^{15} \mathrm{~N}-\mathrm{NO}_{3}^{-}$addition experiment. Background concentrations of $\mathrm{NO}_{3}^{-}$were determined prior to the start of the experiment using soil subsamples $(n=5$ per elevation), after which the soils from each habitat were divided into three treatment groups, and supplemented with surplus $\mathrm{NO}_{3}^{-}$which raised these background levels by $+50,+100$, and $+150 \%$ (Table 2). The $\mathrm{NO}_{3}^{-}$added to the soil in each of the treatments was enriched with ${ }^{15} \mathrm{~N}$ in order to trace the conversion of nitrate to gaseous $\mathrm{N}$ products $\left({ }^{15} \mathrm{~N}-\mathrm{N}_{2} \mathrm{O},{ }^{15} \mathrm{~N}-\right.$ $\mathrm{N}_{2}$ ) (Baggs et al., 2003; Bateman and Baggs, 2005).

Soil cores were sampled from $0-10 \mathrm{~cm}$ for each habitat ( $n=6$ soil cores per habitat), with the exception of upper montane forest, where two separate sets of cores were collected, one from the organic layer (O horizon; $n=6)$ and the other from the mineral layer (A horizon; $n=6$ ). Soil samples were then shipped to the University of Aberdeen and sampled within 1 week of arrival. Transport times from Peru to the UK varied between 1 and 2 weeks. Five of these soil cores, one for each replicate, were split into four equal parts (three treatment samples and one control sample) and distributed into $1 \mathrm{~L}$ screw top jars (Kilner, UK). A small soil subsample from each core was used to determine WFPS, background $\mathrm{NO}_{3}^{-}$content (extracted in $100 \mathrm{~mL} 1 \mathrm{M} \mathrm{KCl}$ for a $10 \mathrm{~g}$ soil sample prior to the start of the experiment), as well as total $\mathrm{C}$ and $\mathrm{N}$ content. If necessary, the samples were gravimetrically amended with water until the cores reached $80 \%$ WFPS. Soil cores were kept under constant conditions for 3 days before the start of the experiment to minimize the effects of changing water content on soil processes.

At the start of the experiment, dissolved ${ }^{15} \mathrm{~N}$-labelled $\mathrm{KNO}_{3}$ (30 at. \%) was added according to the measured $\mathrm{NO}_{3}^{-}$concentrations of each core to reach the required $\mathrm{NO}_{3}^{-}$concentration for each treatment (Table 2). Initial $\mathrm{NO}_{3}^{-}$concentration (prior to ${ }^{15} \mathrm{~N}$ addition) averaged ( \pm standard error) $157 \pm 12 \mu \mathrm{g} \mathrm{Ng} \mathrm{soil}^{-1}$ for pre-montane forest, $140 \pm 12 \mu \mathrm{g} \mathrm{Ng} \mathrm{soil}{ }^{-1}$ for lower montane forest, $19 \pm 7 \mu \mathrm{g} \mathrm{Ng} \mathrm{soil}{ }^{-1}$ for upper montane forest organic layer soil, $18 \pm 5 \mu \mathrm{g} \mathrm{Ng} \mathrm{soil}{ }^{-1}$ for upper montane forest mineral layer soil, and $6 \pm 2 \mu \mathrm{g} \mathrm{Ng} \mathrm{soil}{ }^{-1}$ for montane grassland soil 
(Table 2). The jars were then sealed with lids fitted with a two-way stopcock to allow for gas sampling. Gas samples were taken with gastight syringes, and stored in preevacuated containers for determination of ${ }^{15} \mathrm{~N}-\mathrm{N}_{2},{ }^{15} \mathrm{~N}-$ $\mathrm{N}_{2} \mathrm{O}, \mathrm{N}_{2} \mathrm{O}, \mathrm{CO}_{2}$, and $\mathrm{CH}_{4}$ content. Isotope samples $(150 \mathrm{~mL})$ were stored in $100 \mathrm{~mL}$ serum bottles and gas concentration samples $\left(20 \mathrm{~mL}\right.$ ) were stored in $12 \mathrm{~mL}$ Exetainers ${ }^{\circledR}$ (Labco Ltd., Lampeter, UK). After gas sampling, the stopcock was opened to allow the sampled air from the jar to be replaced by lab air, and lab air was sampled to allow for correction of the gas concentrations in the jars due to dilution. Samples were taken at $0,6,12,24,36$, and $48 \mathrm{~h}$, after which the jars were opened and soil was sampled for determination of $\mathrm{NO}_{3}^{-}, \mathrm{NH}_{4}^{+}$and total $\mathrm{C}$ and N. Gas flux, isotopic and elemental concentrations were determined according to the methods described previously.

\subsection{Statistics}

Statistical analyses were performed using JMP IN Version 8 (SAS Institute, Inc., Cary, North Carolina, USA) or R (R Team, 2012). Residuals were checked for heteroscedasticity and homogeneity of variances. Where necessary, the data were transformed using a Box-Cox procedure to meet the assumptions of analysis of variance. Analysis of variance (ANOVA) or generalized linear models were used to evaluate the effect of categorical variables (i.e. site, season, topography) on trace gas flux and environmental variables. Analysis of covariance (ANCOVA) was performed on Box-Cox transformed data to investigate the combined effects of categorical variables and environmental factors (e.g. water-filled pore space, soil oxygen content, air temperature, soil temperature) on trace gas flux. Non-parametric tests were employed where Box-Cox transformation was unable to normalize the data or homogenize the variances, or where the residuals still showed strong trends even after Box-Cox transformation. Means comparisons were performed using Fisher's least significant difference test (Fisher's LSD). Statistical significance was determined at the $P<0.05$ level unless otherwise noted. Values are reported as means and standard errors ( $\pm 1 \mathrm{SE})$. Statistical analyses for the field data were conducted on plot-averaged data to avoid pseudo-replication.

\section{Results}

\subsection{Variations in $\mathrm{N}_{2} \mathrm{O}$ flux among habitats and between seasons}

The overall mean $\mathrm{N}_{2} \mathrm{O}$ flux for the entire dataset was $0.27 \pm 0.07 \mathrm{mg} \mathrm{N}-\mathrm{N}_{2} \mathrm{O} \mathrm{m}^{-2} \mathrm{~d}^{-1}$, with a range from -8.40 to $75.0 \mathrm{mg} \mathrm{N}-\mathrm{N}_{2} \mathrm{O} \mathrm{m}^{-2} \mathrm{~d}^{-1}$. We investigated the effect of habitat, season, topography, and the interaction of habitat by season on $\mathrm{N}_{2} \mathrm{O}$ flux by using a three-way ANOVA on plotaveraged data $\left(F_{10,307}=3.28, P<0.0005\right.$; Supplement Table S1a). We found that there was a significant effect of habi- tat $(P<0.003)$ and an effect of season at the borderline of statistical significance $(P<0.07)$. However, we found no effect of topography and no habitat by season interaction effect on $\mathrm{N}_{2} \mathrm{O}$ flux. Habitat accounted for the largest proportion of variance in the dataset $(4.3 \%)$, while season accounted for only $1.0 \%$ of the variance (Supplement Table S1a).

Among habitats, the overall trend was towards the highest flux from premontane forest $(0.75 \pm 0.18 \mathrm{mg} \mathrm{N}-$ $\mathrm{N}_{2} \mathrm{Om}^{-2} \mathrm{~d}^{-1}$ ), followed by lower montane forest

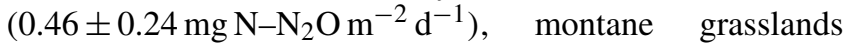
$\left(0.07 \pm 0.08 \mathrm{mg} \mathrm{N}^{-\mathrm{N}_{2}} \mathrm{O} \mathrm{m}^{-2} \mathrm{~d}^{-1}\right)$, and upper montane forest $\left(0.04 \pm 0.07 \mathrm{mg} \mathrm{N}_{-} \mathrm{N}_{2} \mathrm{O} \mathrm{m}^{-2} \mathrm{~d}^{-1}\right)$ (Fig. 2a). Multiple comparisons tests indicated that only premontane forests showed statistically higher flux than the others (Fisher's LSD, $P<0.05$ ); while there were numerical differences in mean flux among the other habitats, large variances meant that they had overlapping ranges of flux (Fig. 2a).

The borderline significant effect of season $(P<0.07)$ reflected an overall trend of higher dry season $\left(0.51 \pm 0.18 \mathrm{mg} \mathrm{N}^{-\mathrm{N}_{2}} \mathrm{O} \mathrm{m}^{-2} \mathrm{~d}^{-1}\right)$ compared to wet season

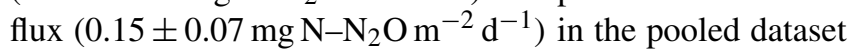
(Table 3). However, part of why the effect of season was weak was because only lower montane forest showed significant variability between seasons (Fisher's LSD, $P<0.05$ ), while the other three habitats did not show significant seasonal differences in flux (Fisher's LSD, $P<0.05$ ).

Even though the effect of topography alone was not statistically significant, $\mathrm{N}_{2} \mathrm{O}$ fluxes from flat sites were significantly higher $\left(0.62 \pm 0.28 \mathrm{mg} \mathrm{N}-\mathrm{N}_{2} \mathrm{O} \mathrm{m}^{-2} \mathrm{~d}^{-1}\right)$ than from the basin site $\left(-0.18 \pm 0.16 \mathrm{mg} \mathrm{N}_{-} \mathrm{N}_{2} \mathrm{O} \mathrm{m}^{-2} \mathrm{~d}^{-1}\right)$ (Fisher's LSD, $P<0.05$ ). However, there was no significant difference between flat sites and either slope or ridge sites

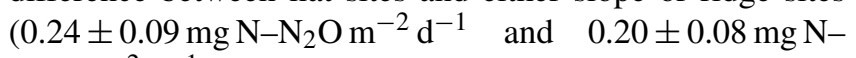
$\mathrm{N}_{2} \mathrm{O} \mathrm{m}^{-2} \mathrm{~d}^{-1}$, respectively) (Fisher's LSD, $P>0.05$ ).

For each habitat, we also compared individual wet and dry seasons against each other using multiple comparisons tests (e.g. dry season 2012 versus wet season 2012, dry season 2012 versus dry season 2013) to determine whether there was significant inter-annual (i.e. year-on-year) variation in $\mathrm{N}_{2} \mathrm{O}$ flux among seasons. Consistent with our three-way ANOVA results, we found that only lower montane forest showed significant variation among multiple dry and wet seasons, whereas the other habitats showed no significant trends. For lower montane forest, we observed significantly higher dry season flux in 2011 compared to wet and dry seasons in all other years $(P<0.05$; Fig. 3b).

\subsection{Variations in environmental conditions among habitats and between seasons}

We investigated the effect of habitat, season, topography, and the interaction of habitat by season on environmental variables using a three-way ANOVA on plot-averaged data. The environmental variables examined here were water-filled pore space (WFPS) in the $0-10 \mathrm{~cm}$ depth, gas-phase soil 


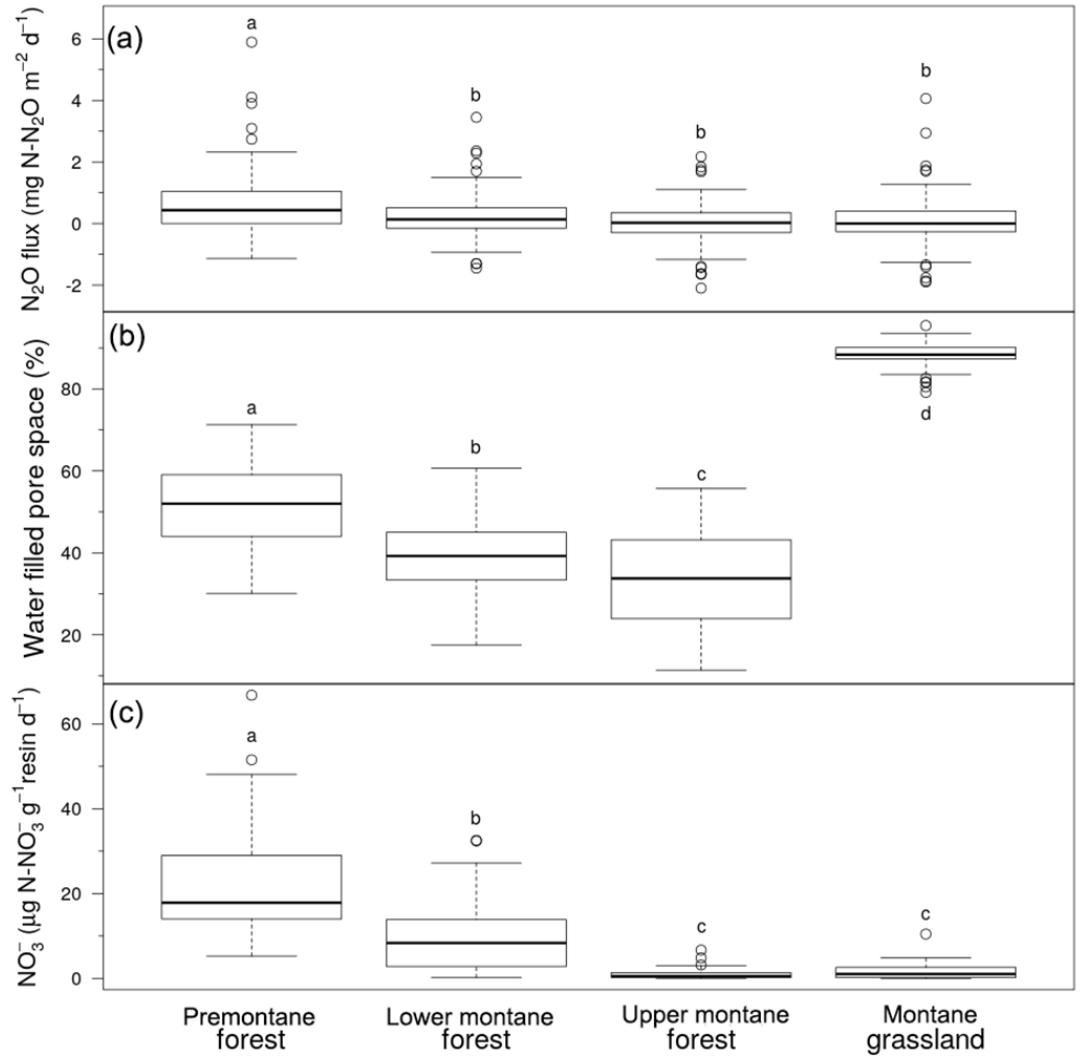

Figure 2. Plot-averaged (a) net $\mathrm{N}_{2} \mathrm{O}$ flux, (b) water-filled pore space, and (c) resin-extractable $\mathrm{NO}_{3}^{-}$flux among habitats. Boxes enclose the interquartile range, whiskers indicate the 90 th and 10th percentiles. Lower case letters indicate statistically significant differences among means (Fisher's LSD, $P<0.05$ ).

oxygen content in the $0-10 \mathrm{~cm}$ depth, soil temperature, air temperature, and resin-extractable inorganic $\mathrm{N}$ flux $\left(\mathrm{NH}_{4}^{+}\right.$, $\mathrm{NO}_{3}^{-}$).

Water-filled pore space varied significantly as a function of habitat, season, habitat by season, and topography $\left(F_{10,304}=637.96, P<0.0001\right.$; Table 3; Figs. 2b, 3; Supplement Table S1b). Habitat accounted for the largest proportion of variance in the model $(78.1 \%)$, followed by season $(0.6 \%)$, habitat by season interaction $(0.6 \%)$, and topography $(0.4 \%)$ (Supplement Table S1b). Each habitat differed significantly from the others (Fisher's LSD, $P<0.05$ ), with the highest WFPS observed in montane grassland $(88.4 \pm 0.3 \%)$, followed by premontane forest $(51.6 \pm 1.3 \%)$, lower montane forest $(39.0 \pm 0.9 \%)$, and upper montane forest $(35.0 \pm 1.5 \%)$ (Fig. 2b). WFPS varied significantly between seasons ( $t$ test, $P<0.05$ ), with a mean dry season value of $52.1 \pm 2.4 \%$ compared to a mean wet season value of $59.5 \pm 1.6 \%$ (Table 3 ). The significant habitat by season interaction is due to the fact that some habitats showed seasonal trends in WFPS whereas others did not. Whereas lower montane and upper montane forests all showed a significant reduction in WFPS during the dry season, premontane forest and montane grasslands showed no seasonal differences in WFPS (Table 3, Fig. 3). For topography, the main effect was that the basin landform had significantly higher WFPS than the other landforms. The basin landform showed a mean WFPS of $89.3 \pm 0.1 \%$, whereas WFPS in other landforms ranged from $51.7 \pm 2.2$ to $57.7 \pm 2.7 \%$.

Soil oxygen in the $0-10 \mathrm{~cm}$ depth varied significantly as a function of habitat, habitat by season, and topography $\left(F_{10,242}=27.70, P<0.0001\right.$; Table 3 ; Supplement Table S1c). Habitat accounted for the largest proportion of variance in the model $(66.9 \%$ of the total variance), followed by topography $(8.4 \%)$, habitat by season $(3.5 \%)$ (Supplement Table S1c). For habitat, multiple comparisons tests indicated that only montane grasslands showed significantly lower soil $\mathrm{O}_{2}$ content than the other habitats $(13.5 \pm 0.6 \%)$, while the others showed statistically similar soil $\mathrm{O}_{2}$ values to each other $(18.6 \pm 0.2$ to $19.5 \pm 0.1 \%$; Fisher's LSD, $P<0.05)$. For topography, multiple comparisons tests indicated that the basin landform showed statistically lower soil $\mathrm{O}_{2}$ content than the other landforms $(7.4 \pm 2.3 \%)$, whereas the other topographic features showed statistically similar values, ranging from $16.9 \pm 0.6$ to $18.2 \pm 0.2 \%$ (Fisher's LSD, $P<0.05)$. The significant habitat by season interac- 
(a)

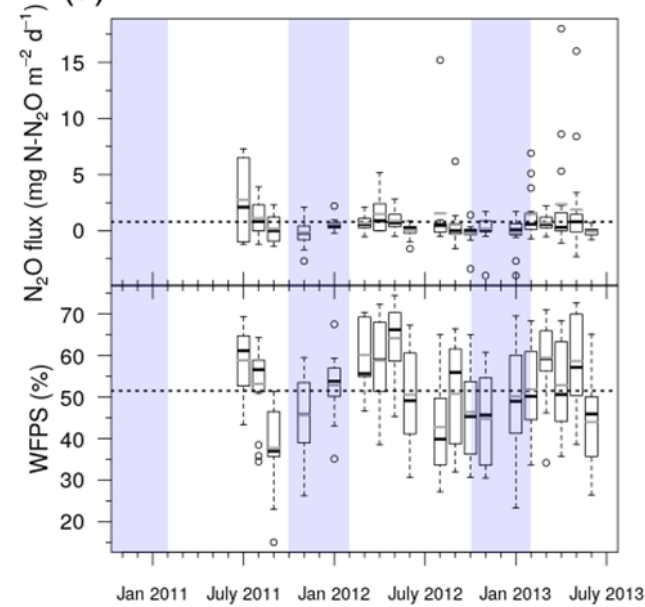

(b)

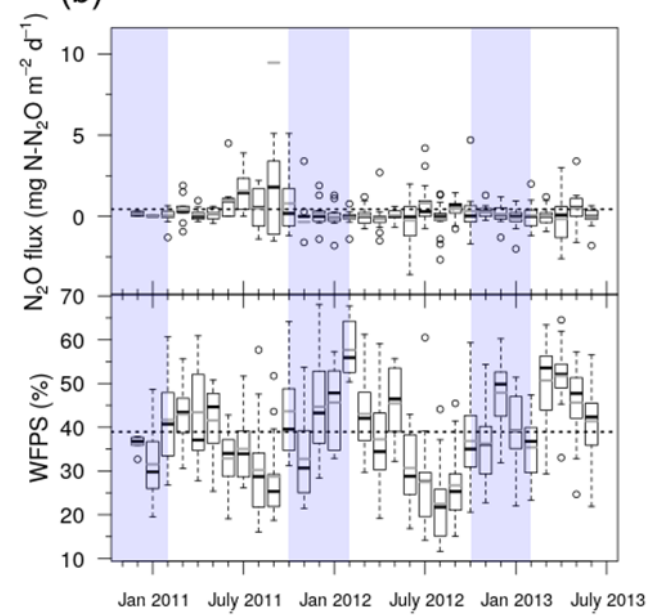

(c)

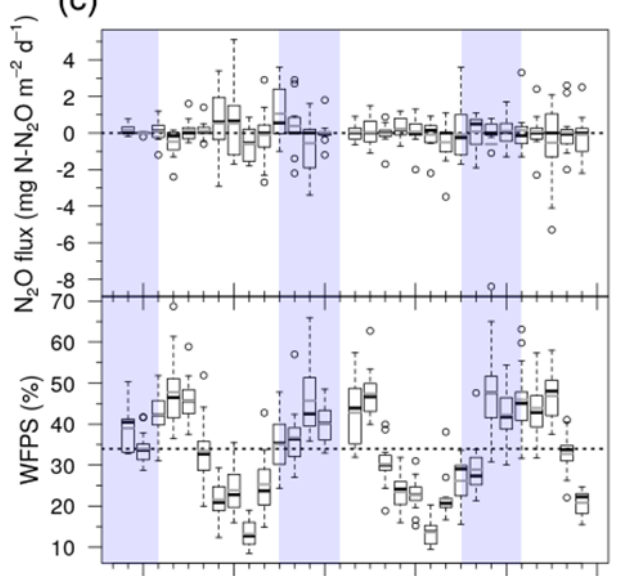

Jan 2011 July 2011 Jan 2012 July 2012 Jan 2013 July 2013

(d)

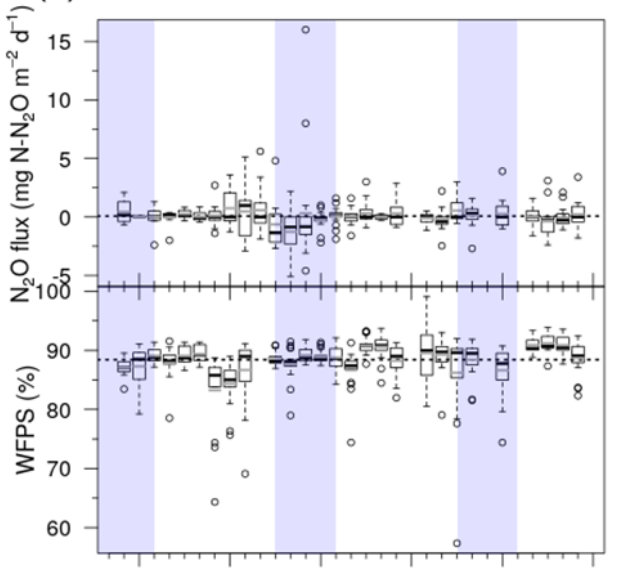

Jan 2011 July 2011 Jan 2012 July 2012 Jan 2013 July 2013

Figure 3. Time series of net $\mathrm{N}_{2} \mathrm{O}$ flux and water-filled pore space (WFPS). Panels indicate data for (a) premontane forest, (b) lower montane forest, (c) upper montane forest, and (d) montane grasslands for the 30-month study period beginning in January 2011 and ending in June 2013. The broken horizontal line running across each panel denotes the overall mean $\mathrm{N}_{2} \mathrm{O}$ flux or WFPS for that habitat. The dashed line in each box indicate median values and the black lines indicate means. Dry and wet seasons are denoted by vertical shading on the graph, with the dry season (May to September) highlighted in white and the wet season (October to April) in light blue.

tion was due to the fact that only montane grassland showed a significant difference in $\mathrm{O}_{2}$ content between wet and dry season, whereas other habitats showed similar soil $\mathrm{O}_{2}$ values (Table 3).

For soil temperature, the effects of habitat, season, habitat by season, and topography were all significant $\left(F_{10,292}=\right.$ 790.7, $P<0.0001$; Supplement Table S1d). Habitat accounted for the largest proportion of variance in the model $(85.5 \%$ of the total variance), followed by season $(1.4 \%)$, habitat by season interaction $(0.5 \%)$, and topography $(0.3 \%)$ (Supplement Table S1d). Each habitat differed significantly from the others (Fisher's LSD, $P<0.05$ ), with the highest soil temperature observed for premontane forest $\left(20.5 \pm 0.1^{\circ} \mathrm{C}\right)$, followed by lower montane forest $\left(17.8 \pm 0.1^{\circ} \mathrm{C}\right)$, upper montane forest $\left(11.5 \pm 0.1^{\circ} \mathrm{C}\right)$, and montane grasslands $\left(10.6 \pm 0.2^{\circ} \mathrm{C}\right)$. Soil temperature varied significantly between season $(t$ test, $P<0.05)$, with a mean dry season value of $13.9 \pm 0.4^{\circ} \mathrm{C}$ compared to a mean wet season value of $15.1 \pm 0.3^{\circ} \mathrm{C}$. The significant habitat by season interaction is due to the fact that some habitats showed more pronounced seasonal trends in soil temperature than others, although the overall pattern of cooler dry season compared to wet season soil temperatures holds across all habitats (Table 3). For topography, the flat landforms showed significantly higher soil temperatures than the others $\left(16.0 \pm 0.5^{\circ} \mathrm{C}\right)$, the basin landform showed significantly lower values $\left(10.8 \pm 0.4^{\circ} \mathrm{C}\right)$, whereas ridge and slope landforms showed similar values to each other $(14.3 \pm 0.4$ and $14.7 \pm 0.4^{\circ} \mathrm{C}$, respectively) (Fisher's LSD, $P<0.05$ ). 


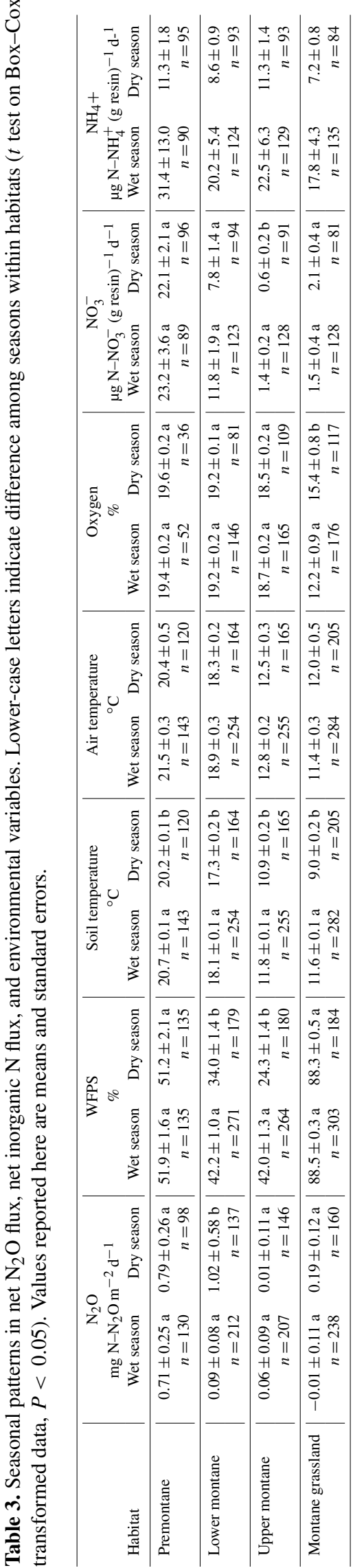

For air temperature, only the effect of habitat was significant $\left(F_{10,292}=103.2, P<0.0001\right.$; Tables 3 , S1e $)$. A multiple comparisons test indicated that each habitat showed significantly different temperatures compared to the others (Fisher's LSD, $P<0.05$ ). Premontane forest showed the highest air temperatures $\left(21.0 \pm 0.3^{\circ} \mathrm{C}\right)$, followed by lower montane forest $\left(18.7 \pm 0.2^{\circ} \mathrm{C}\right)$, upper montane forest $\left(12.7 \pm 0.2^{\circ} \mathrm{C}\right)$, and montane grassland $\left(11.7 \pm 0.3^{\circ} \mathrm{C}\right)$. Other variables did not significantly affect air temperature.

For resin-extractable $\mathrm{NH}_{4}^{+}$flux, even though the three-way ANOVA model was not statistically significant, the overall trend was towards significantly lower $\mathrm{NH}_{4}^{+}$flux in the dry season $\left(9.6 \pm 0.7 \mu \mathrm{g} \mathrm{N}-\mathrm{NH}_{4} \mathrm{~g} \mathrm{resin}^{-1} \mathrm{~d}^{-1}\right)$ compared to the wet season $\left(22.3 \pm 3.6 \mu \mathrm{g} \mathrm{N}-\mathrm{NH}_{4} \mathrm{~g} \mathrm{resin}^{-1} \mathrm{~d}^{-1}\right)\left(F_{10,164}=\right.$ $1.3, P>0.2$; Tables 3, S1f).

Resin-extractable $\mathrm{NO}_{3}^{-}$flux showed different patterns from $\mathrm{NH}_{4}^{+}$flux, with significant effects of habitat, topography, and habitat by season but not of season alone $\left(F_{10,164}=39.0, P<0.0001\right.$; Fig. $2 \mathrm{c}$; Tables 3, S1g). Habitat accounted for the largest proportion of the variance $(61.5 \%)$, followed by topography $(4.7 \%)$, and habitat by season $(1.9 \%)$. Premontane forest showed the highest $\mathrm{NO}_{3}^{-}$flux $\left(22.6 \pm 2.0 \mu \mathrm{g} \mathrm{N}-\mathrm{NO}_{3} \mathrm{~g} \mathrm{resin}^{-1} \mathrm{~d}^{-1}\right)$, followed by lower montane forest $\left(10.0 \pm 1.2 \mu \mathrm{g} \mathrm{N}-\mathrm{NO}_{3} \mathrm{~g} \mathrm{resin}^{-1} \mathrm{~d}^{-1}\right)$ (Fisher's LSD, $P<0.05$; Fig. 2c). Upper montane forest $\left(1.1 \pm 0.2 \mu \mathrm{g} \mathrm{N}-\mathrm{NO}_{3} \mathrm{~g} \mathrm{resin}^{-1} \mathrm{~d}^{-1}\right)$ and montane grassland $\left(1.7 \pm 0.3 \mu \mathrm{g} \mathrm{N}-\mathrm{NO}_{3} \mathrm{~g} \mathrm{resin}^{-1} \mathrm{~d}^{-1}\right)$ showed significantly lower $\mathrm{NO}_{3}^{-}$flux than the other two habitats (Fisher's LSD, $P<0.05$; Fig. 2c), with values that were not significantly different from each other (Fisher's LSD, $P>0.05$; Fig. 2c). For the effect of topography, multiple comparisons tests indicated that flat landforms $\left(12.1 \pm 1.8 \mu \mathrm{g} \mathrm{N}-\mathrm{NO}_{3} \mathrm{~g} \mathrm{resin}^{-1} \mathrm{~d}^{-1}\right)$ and slope landforms $\left(10.2 \pm 1.6 \mu \mathrm{g} \mathrm{N}-\mathrm{NO}_{3} \mathrm{~g} \mathrm{resin}^{-1} \mathrm{~d}^{-1}\right)$ differed significantly from ridge landforms $(6.6 \pm 1.4 \mu \mathrm{g} \mathrm{N}-$ $\mathrm{NO}_{3} \mathrm{~g} \mathrm{resin}^{-1} \mathrm{~d}^{-1}$ ) (Fisher's LSD, $P<0.05$ ). The basin landform $\left(3.8 \pm 1.3 \mu \mathrm{g} \mathrm{N}-\mathrm{NO}_{3}\right.$ g resin $\left.^{-1} \mathrm{~d}^{-1}\right)$, despite the lower mean values, showed an overlapping range with the other landforms (Fisher's LSD, $P>0.05$ ). The habitat by season interaction was due to the fact that upper montane forest shows a significant seasonal fluctuation in resinextractable $\mathrm{NO}_{3}^{-}$(Fisher's LSD, $P<0.05$ ), whereas the other habitats show no significant seasonal trend (Fisher's LSD, $P>0.05$; Table 3).

\subsection{Effects of environmental variables on $\mathrm{N}_{2} \mathrm{O}$ flux}

For the whole dataset, the relationship between $\mathrm{N}_{2} \mathrm{O}$ flux and environmental variables was examined using an ANCOVA on Box-Cox transformed data with habitat, season, topography, and environmental variables as covariates. Environmental variables included WFPS, oxygen, air temperature, soil temperature, and resin-extractable inorganic $\mathrm{N}$ flux $\left(\mathrm{NH}_{4}^{+}\right.$ and $\mathrm{NO}_{3}^{-}$). The ANCOVA model as a whole was not statistically significant $(P>0.4)$. However, we found that indi- 
vidual factors were weakly but significantly correlated with $\mathrm{N}_{2} \mathrm{O}$ flux for the pooled dataset. These included soil temperature $\left(r^{2}=0.04, P<0.0004\right)$, air temperature $\left(r^{2}=0.04\right.$, $P<0.0008)$, and resin-extractable $\mathrm{NO}_{3}^{-}$flux $\left(r^{2}=0.03\right.$, $P<0.03)$. Water-filled pore space also showed a very weak negative correlation with $\mathrm{N}_{2} \mathrm{O}$ flux at the borderline of statistical significance $\left(r^{2}=0.01, P<0.06\right)$.

For individual habitats, we explored how variations in environmental conditions influenced $\mathrm{N}_{2} \mathrm{O}$ flux using multiple regression, with WFPS, oxygen, soil temperature, air temperature, resin-extractable $\mathrm{NH}_{4}^{+}$flux, and resin-extractable $\mathrm{NO}_{3}^{-}$ flux as explanatory variables. Only the multiple regression analysis for lower montane forest showed a borderline significant result, though only at the $P<0.07$ level $\left(r^{2}=0.36\right)$. The multiple regression models for all the other habitats were not statistically significant $(P>0.4)$. Lower montane forest was the only habitat that showed a significant effect of season on $\mathrm{N}_{2} \mathrm{O}$ flux (Sect. 5.1), and our multiple regression model corroborated this result by showing that seasonal fluctuations in air temperature, soil temperature, WFPS (Fig. 3b), and $\mathrm{NH}_{4}^{+}$all correlated with $\mathrm{N}_{2} \mathrm{O}$ flux $(P<0.05)$. Air temperature explained the largest proportion of variance in the data $(26.2 \%$; negative trend), followed by soil temperature ( $15.5 \%$; positive trend), WFPS $(13.7 \%$; negative trend), and resin-extractable $\mathrm{NH}_{4}^{+}$flux (11.6\%; negative trend).

\subsection{Water-filled pore space manipulation}

${ }^{15} \mathrm{~N}-\mathrm{N}_{2} \mathrm{O}$ and ${ }^{15} \mathrm{~N}-\mathrm{N}_{2}$ fluxes showed a biphasic response (Limmer and Steele, 1982), with significantly different flux rates in the first $24 \mathrm{~h}$ of incubation compared to the later period of incubation (i.e. $24-48 \mathrm{~h}$ ). Flux of ${ }^{15} \mathrm{~N}-\mathrm{N}_{2} \mathrm{O}$, and ${ }^{15} \mathrm{~N}-$ $\mathrm{N}_{2}$, were therefore divided into early $(0-24 \mathrm{~h})$ and late (24$48 \mathrm{~h}$ ) phase flux.

\subsubsection{Role of nitrification and nitrate reduction in $\mathrm{N}_{2} \mathrm{O}$ production}

The ${ }^{15} \mathrm{~N}$ flux data indicate that nitrate reduction (i.e. denitrification) was the dominant source of $\mathrm{N}_{2} \mathrm{O}$ from these soils, while nitrification was only a minor contributor to ${ }^{15} \mathrm{~N}-\mathrm{N}_{2} \mathrm{O}$ production (Supplement Fig. S1). The ${ }^{15} \mathrm{~N}-\mathrm{N}_{2} \mathrm{O}$ and ${ }^{15} \mathrm{~N}-\mathrm{N}_{2}$ fluxes were analysed using a full factorial ANOVA on BoxCox transformed data with habitat, moisture level, form of ${ }^{15} \mathrm{~N}$-label added (i.e. ${ }^{15} \mathrm{NH}_{4}^{15} \mathrm{NO}_{3}$ or ${ }^{14} \mathrm{NH}_{4}^{15} \mathrm{NO}_{3}$ ), incubation phase, and all their interaction terms as independent variables. Notably, this analysis revealed that the form of ${ }^{15} \mathrm{~N}$ label added (i.e. ${ }^{15} \mathrm{~N}-\mathrm{NH}_{4}^{15} \mathrm{~N}-\mathrm{NO}_{3}$ or ${ }^{14} \mathrm{~N}-\mathrm{NH}_{4}^{15} \mathrm{~N}-\mathrm{NO}_{3}$ ) did not significantly alter ${ }^{15} \mathrm{~N}-\mathrm{N}_{2} \mathrm{O}$ flux, indicating that production of ${ }^{15} \mathrm{~N}-\mathrm{N}_{2} \mathrm{O}$ from nitrification was weak to negligible (Supplement Fig. S1). In order to simplify our statistical analyses, all subsequent analyses were performed using only habitat, moisture level, incubation phase, and their interaction terms as independent variables. For these tests, which are described below, the "total" flux of ${ }^{15} \mathrm{~N}-\mathrm{N}_{2} \mathrm{O}$ or ${ }^{15} \mathrm{~N}-\mathrm{N}_{2}$ represents gas produced by both nitrification and nitrate reduction.

\subsection{2 ${ }^{15} \mathrm{~N}-\mathrm{N}_{2} \mathrm{O}$ flux}

For the total ${ }^{15} \mathrm{~N}-\mathrm{N}_{2} \mathrm{O}$ flux data, we used a full factorial ANOVA on Box-Cox transformed data with habitat, moisture level, incubation phase, and all their interactions as independent variables. We found that moisture level, habitat by incubation phase, and habitat by moisture by incubation phase were significantly related to ${ }^{15} \mathrm{~N}-$ $\mathrm{N}_{2} \mathrm{O}$ flux (ANOVA, $F_{31,321}=3.06, P<0.0001$; Fig. 4; Supplement Table S2a). Of the three main factors (i.e. habitat, moisture level, incubation phase), moisture level was the dominant control on ${ }^{15} \mathrm{~N}-\mathrm{N}_{2} \mathrm{O}$ flux (Supplement Table S2a). The highest ${ }^{15} \mathrm{~N}-\mathrm{N}_{2} \mathrm{O}$ flux was observed in the $90 \%$ WFPS $\left(42 \pm 9 \mathrm{ng} \mathrm{N}_{2} \mathrm{O}-{ }^{15} \mathrm{Ng}^{-1} \mathrm{~d}^{-1}\right)$ and $50 \%$ WFPS $\left(29 \pm 10 \mathrm{ng} \mathrm{N}_{2} \mathrm{O}-{ }^{15} \mathrm{Ng}^{-1} \mathrm{~d}^{-1}\right)$ treatments, and the lowest flux in the $30 \%\left(3 \pm 1 \mathrm{ng} \mathrm{N} \mathrm{N}_{2} \mathrm{O}-{ }^{15} \mathrm{~N} \mathrm{~g}^{-1} \mathrm{~d}^{-1}\right)$ and $70 \%\left(7 \pm 2 \mathrm{ng} \mathrm{N}_{2} \mathrm{O}-{ }^{15} \mathrm{~N} \mathrm{~g}^{-1} \mathrm{~d}^{-1}\right)$ treatments (Fisher's LSD, $P<0.05$; Fig. 4). The habitat by incubation phase interaction indicated that some habitats showed different flux rates during early and late phases of the incubation (Fig. 4). Premontane and lower montane forest showed statistically similar ${ }^{15} \mathrm{~N}-\mathrm{N}_{2} \mathrm{O}$ flux during early and late incubation phases. Upper montane forest mineral layer soils showed a significant increase in ${ }^{15} \mathrm{~N}-\mathrm{N}_{2} \mathrm{O}$ flux from early to late incubation phases $\left(5 \pm 2 \mathrm{ng} \mathrm{N}_{2} \mathrm{O}-{ }^{15} \mathrm{Ng}^{-1} \mathrm{~d}^{-1}\right.$ versus $42 \pm 13 \mathrm{ng} \mathrm{N}_{2} \mathrm{O}-$ ${ }^{15} \mathrm{Ng}^{-1} \mathrm{~d}^{-} 1 ; t$ test, $P<0.003$ ), while montane grasslands showed a significant decrease in ${ }^{15} \mathrm{~N}-\mathrm{N}_{2} \mathrm{O}$ flux from early to late incubation phases $\left(60 \pm 23 \mathrm{ng} \mathrm{N}_{2} \mathrm{O}-{ }^{15} \mathrm{Ng}^{-1} \mathrm{~d}^{-1}\right.$ versus $6 \pm 9 \mathrm{ng} \mathrm{N}_{2} \mathrm{O}-{ }^{15} \mathrm{Ng}^{-1} \mathrm{~d}^{-1}$, respectively; $t$ test, $P<0.02$ ). The habitat by moisture by incubation phase effect stems from complex and varying responses of soils from different habitats to differences in moisture level and incubation phase (Fig. 4).

\section{$3.5{ }^{15} \mathrm{~N}-\mathrm{N}_{2}$ flux}

For the total ${ }^{15} \mathrm{~N}-\mathrm{N}_{2}$ flux data, we used a full factorial ANOVA on Box-Cox transformed data with habitat, moisture level, incubation phase, and all their interactions as independent variables. We found that all of the main factors and their interaction terms were statistically significant (ANOVA, $F_{31,317}=14.20, P<0.0001$; Supplement Table S2b). Of the three main factors, habitat was the dominant control on ${ }^{15} \mathrm{~N}-\mathrm{N}_{2}$ flux (Supplement Table S2b). Lower montane forest showed the highest ${ }^{15} \mathrm{~N}-\mathrm{N}_{2}$ flux (694 $\pm 83 \mathrm{ng} \mathrm{N}_{2}-{ }^{15} \mathrm{~N} \mathrm{~g}^{-1} \mathrm{~d}^{-1}$ ); premontane forest and upper montane forest mineral layer soil showed intermediate levels of flux (326 \pm 53 and $171 \pm 20 \mathrm{ng} \mathrm{N}_{2}-{ }^{15} \mathrm{~N} \mathrm{~g}^{-1} \mathrm{~d}^{-1}$, respectively); and montane grassland soil showed the lowest flux $\left(123 \pm 23 \mathrm{ng} \mathrm{N}_{2} \mathrm{O}-{ }^{15} \mathrm{Ng}^{-1} \mathrm{~d}^{-1}\right)$ (Fisher's LSD, $P<0.05$; Fig. 4). Moisture played a secondary role in regulating ${ }^{15} \mathrm{~N}-$ $\mathrm{N}_{2}$ flux (Supplement Table S2B), with only the $90 \%$ treat- 


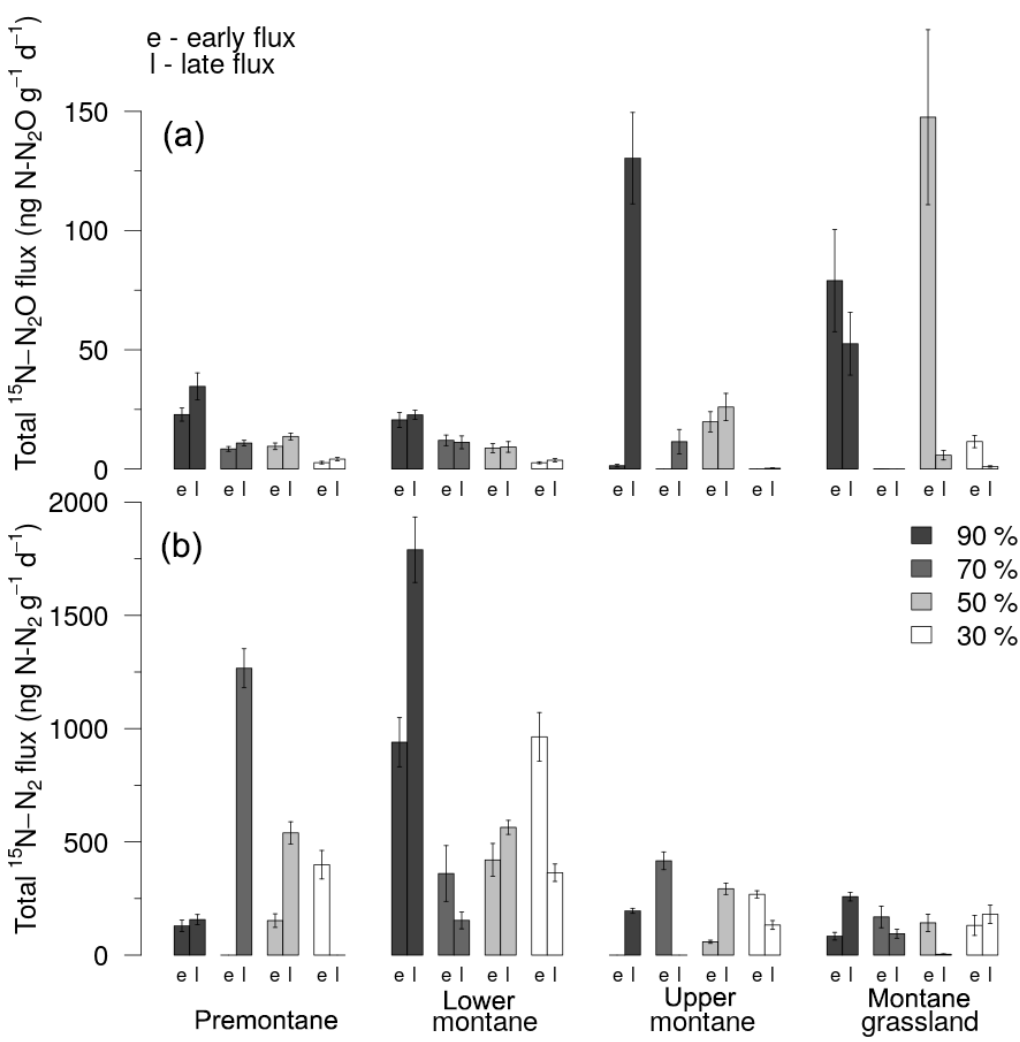

Figure 4. Total (a) ${ }^{15} \mathrm{~N}-\mathrm{N}_{2} \mathrm{O}$ flux and (b) ${ }^{15} \mathrm{~N}-\mathrm{N}_{2}$ flux during the early ( $\leq 24 \mathrm{~h}$ ) and late $(>24 \mathrm{~h})$ incubation phases of the water-filled pore space (WFPS) experiment. Results from the $90 \%$ WFPS treatment are shown in dark grey, while data from the 70, 50, and $30 \%$ WFPS treatments are shown in mid grey, light grey, and white, respectively. The bar charts show means and standard errors.

ment having significantly higher flux than the other treatments (90\% WFPS treatment: $437 \pm 77 \mathrm{ng} \mathrm{N}_{2}{ }^{15} \mathrm{~N} \mathrm{~g}^{-1} \mathrm{~d}^{-1}$; pooled average for all other treatments: $294 \pm 28 \mathrm{ng} \mathrm{N}_{2}-$ ${ }^{15} \mathrm{Ng}^{-1} \mathrm{~d}^{-1}$ ) (Fisher's LSD, $P<0.05$ ). Incubation phase was the least important control on ${ }^{15} \mathrm{~N}-\mathrm{N}_{2}$ flux, with slightly greater flux of ${ }^{15} \mathrm{~N}-\mathrm{N}_{2}$ during the late compared to the early phase of the incubations $\left(373 \pm 44 \mathrm{ng} \mathrm{N}_{2}-{ }^{15} \mathrm{~N} \mathrm{~g}^{-1} \mathrm{~d}^{-1}\right.$ versus $\left.288 \pm 37 \mathrm{ng} \mathrm{N}_{2}{ }^{15} \mathrm{Ng}^{-1} \mathrm{~d}^{-1}\right)(t$ test, $P<0.07)$. The habitat by moisture level interaction indicates that flux from different habitats showed varying moisture responses (Fig. 4). For example, ${ }^{15} \mathrm{~N}-\mathrm{N}_{2}$ flux from premontane forest and upper montane forest mineral layer soil showed no responses to moisture. In contrast, for lower montane forest, flux was greatest for the $90 \%$ WFPS treatment $\left(1365 \pm 201 \mathrm{ng} \mathrm{N}_{2}{ }^{15} \mathrm{~N} \mathrm{~g}^{-1} \mathrm{~d}^{-1}\right)$, lowest for the $70 \%$ WFPS treatment $\left(257 \pm 128 \mathrm{ng} \mathrm{N}_{2}-^{15} \mathrm{Ng}^{-1} \mathrm{~d}^{-1}\right)$, and at intermediate levels for the $30 \%$ and $50 \%$ WFPS treatments (664 \pm 131 and $492 \pm 79 \mathrm{ng} \mathrm{N}_{2}-{ }^{15} \mathrm{Ng}^{-1} \mathrm{~d}^{-1}$, respectively) (Fisher's LSD, $P<0.05$ ). The pattern for montane grassland was different again; here, only the $90 \%$ WFPS treatment showed significantly greater flux $\left(171 \pm 32 \mathrm{ng} \mathrm{N}_{2}-\right.$ ${ }^{15} \mathrm{Ng}^{-1} \mathrm{~d}^{-1}$ ) compared to the other treatments (pooled average: $105 \pm 29 \mathrm{ng} \mathrm{N}_{2}{ }^{15} \mathrm{Ng}^{-1} \mathrm{~d}^{-1}$ ) (Fisher's LSD, $P<$ $0.05)$.

\subsection{1 $\quad \mathrm{N}_{2} \mathrm{O}$ yield}

For the $\mathrm{N}_{2} \mathrm{O}$ yield, we used a full factorial ANOVA on BoxCox transformed data with habitat, moisture level, incubation phase, and all their interactions as independent variables. We found that habitat, moisture level, habitat by moisture level, habitat by phase, and habitat by moisture level by phase significantly influenced $\mathrm{N}_{2} \mathrm{O}$ yield (ANOVA, $F_{31,313}=9.85$, $P<0.0001$; Supplement Table S2c). Of the three main factors, habitat was the best predictor of $\mathrm{N}_{2} \mathrm{O}$ yield (Supplement Table $\mathrm{S} 2 \mathrm{c}$ ). $\mathrm{N}_{2} \mathrm{O}$ yield was highest for the montane grassland $(0.61 \pm 0.06)$, lowest for lower montane forest $(0.19 \pm 0.04)$, while premontane forest and upper montane forest mineral layer soil showed similar intermediate values $(0.40 \pm 0.05$ and $0.42 \pm 0.05$, respectively) (Fisher's LSD, $P<0.05$ ). Moisture level explained much less of the variance in the dataset (Supplement Table $\mathrm{S} 2 \mathrm{c}$ ) $; \mathrm{N}_{2} \mathrm{O}$ yield was highest for the $70 \%$ WFPS treatment $(0.51 \pm 0.06)$, while the 30,50 and $90 \%$ WFPS treatments showed statistically similar values $(0.35 \pm 0.05,0.39 \pm 0.05$, and $0.36 \pm 0.05$, respectively) (Fisher's LSD, $P<0.05$ ). For the habitat by moisture level interaction, this reflects the fact that only lower montane forest and upper montane forest showed differences in $\mathrm{N}_{2} \mathrm{O}$ yield with changes in moisture level. For the lower montane 
forest, $\mathrm{N}_{2} \mathrm{O}$ yield was greatest in the $70 \%$ WFPS treatment $(0.51 \pm 0.11)$, whereas the other treatments were not statistically different from each other (pooled average: $0.09 \pm 0.03$ ) (Fisher's LSD, $P<0.05$ ). Upper montane forest mineral layer soil showed the highest $\mathrm{N}_{2} \mathrm{O}$ yield for the $90 \%$ treatment $(0.72 \pm 0.08)$, lowest yield for the $30 \%$ WFPS treatment $(0.20 \pm 0.09)$, and intermediate $\mathrm{N}_{2} \mathrm{O}$ yields for the 50 and $70 \%$ WFPS treatments $(0.29 \pm 0.09$ and $0.50 \pm 0.11$, respectively) (Fisher's LSD, $P<0.05$ ). For the habitat by incubation phase interaction, this reflects the fact that upper montane forest mineral layer soil showed an increase in $\mathrm{N}_{2} \mathrm{O}$ yield from early to late phase, while montane grassland showed a decrease in $\mathrm{N}_{2} \mathrm{O}$ yield from early to late phase. The habitat by moisture level by incubation phase interaction reflects the complex and varied responses of soils from different habitats to changes in moisture level and incubation phase (Fig. 4).

\subsection{Litter manipulation experiment}

In order to investigate the relationship between leaf litter input rates and $\mathrm{N}_{2} \mathrm{O}$ flux, we used a Generalized Linear Model (GLM) and an ANCOVA that included habitat, litter treatment, season, WFPS, litter input rate, litter $\mathrm{C}$ input rate, litter $\mathrm{N}$ input rate, soil temperature and air temperature as independent variables. The analysis was also repeated using ANCOVA on Box-Cox transformed data. Both analyses revealed no significant statistical relationship between $\mathrm{N}_{2} \mathrm{O}$ flux and any of these environmental variables, with the exception of soil temperature, which showed only a weak positive relationship to $\mathrm{N}_{2} \mathrm{O}$ flux when the data was analysed using the GLM $(P<0.05)$. This relationship was not detected using ANCOVA. Bivariate regression of soil temperature against $\mathrm{N}_{2} \mathrm{O}$ flux indicated that the relationship was relatively weak, with $r^{2}=0.01(P<0.05)$.

\subsection{Nitrate addition experiment}

${ }^{15} \mathrm{~N}-\mathrm{N}_{2} \mathrm{O}$ and ${ }^{15} \mathrm{~N}-\mathrm{N}_{2}$ fluxes showed a biphasic response (Limmer and Steele, 1982), with significantly different flux rates in the first $24 \mathrm{~h}$ of incubation compared to the later period of incubation (i.e. $24-48$ h). Flux of ${ }^{15} \mathrm{~N}-\mathrm{N}_{2} \mathrm{O}$, and ${ }^{15} \mathrm{~N}-$ $\mathrm{N}_{2}$, were therefore divided into early $(0-24 \mathrm{~h})$ and late (24$48 \mathrm{~h}$ ) phase flux.

\subsection{1 ${ }^{15} \mathrm{~N}-\mathrm{N}_{2} \mathrm{O}$ flux}

For the ${ }^{15} \mathrm{~N}-\mathrm{N}_{2} \mathrm{O}$ flux data, we used a full factorial ANOVA on Box-Cox transformed data with habitat, $\mathrm{N}$ addition level, incubation phase, and all their interaction terms as independent variables. Habitat, incubation phase, and the habitat by incubation phase interaction all significantly influenced ${ }^{15} \mathrm{~N}-\mathrm{N}_{2} \mathrm{O}$ flux (ANOVA, $F_{29,149}=5.67, P<0.0001$; Fig. 5; Supplement Table S3a). Notably, $\mathrm{N}$ addition level did not significantly influence ${ }^{15} \mathrm{~N}-\mathrm{N}_{2} \mathrm{O}$ flux. Of the three main factors (i.e. habitat, $\mathrm{N}$ addition level, incubation phase), habitat was the best predictor of ${ }^{15} \mathrm{~N}-\mathrm{N}_{2} \mathrm{O}$ flux, explaining the largest proportion of the variance (Supplement Table S3a). Upper montane forest organic layer soils showed the highest flux $\left(238 \pm 160 \mathrm{ng} \mathrm{N} \mathrm{N}_{2} \mathrm{O}^{15} \mathrm{Ng}^{-1} \mathrm{~d}^{-1}\right)$, lower montane $\left(179 \pm 48 \mathrm{ng} \mathrm{N}_{2} \mathrm{O}-{ }^{15} \mathrm{Ng}^{-1} \mathrm{~d}^{-1}\right)$ and premontane $\left(86 \pm 16 \mathrm{ng} \mathrm{N}_{2} \mathrm{O}-{ }^{15} \mathrm{Ng}^{-1} \mathrm{~d}^{-1}\right)$ forest showed intermediate flux, while montane grasslands $\left(11 \pm 4 \mathrm{ng} \mathrm{N}_{2} \mathrm{O}-\right.$ ${ }^{15} \mathrm{~N} \mathrm{~g}^{-1} \mathrm{~d}^{-1}$ ) and upper montane forest mineral layer soils $\left(0.06 \pm 0.01 \mathrm{ng} \mathrm{N} \mathrm{N}_{2} \mathrm{O}-{ }^{15} \mathrm{Ng}^{-1} \mathrm{~d}^{-1}\right)$ showed the lowest flux (Fisher's LSD, $P<0.05$ ). The effect of incubation phase was attributable to significantly greater ${ }^{15} \mathrm{~N}-\mathrm{N}_{2} \mathrm{O}$ flux during the late compared to early incubation phases $\left(164 \pm 66 \mathrm{ng} \mathrm{N}_{2} \mathrm{O}\right.$ ${ }^{15} \mathrm{Ng}^{-1} \mathrm{~d}^{-1}$ versus $42 \pm 11 \mathrm{ng} \mathrm{N}_{2} \mathrm{O}_{-}{ }^{15} \mathrm{Ng}^{-1} \mathrm{~d}^{-1} ; t$ test, $P<0.05$; Fig. 5). The habitat by incubation phase interaction was caused by some habitats showing higher flux in certain incubation phases than others (Fig. 5). During the early phase, lower montane and premontane forests collectively showed the highest flux (Fig. 5; Fisher's LSD, $P<0.05$ ). In contrast, during the late incubation phase, upper montane forest organic layer soils, lower montane forest, and premontane forest now showed the highest flux (Fig. 5; Fisher's LSD, $P<0.05)$.

\subsection{2 ${ }^{15} \mathrm{~N}-\mathrm{N}_{2}$ flux}

For the ${ }^{15} \mathrm{~N}-\mathrm{N}_{2}$ flux data, we used a full factorial ANOVA on Box-Cox transformed data with habitat, $\mathrm{N}$ addition level, incubation phase, and all their interaction terms as independent variables. Only habitat significantly influenced flux, while other terms were not significant (ANOVA, $F_{29,149}=1.66, P<0.05$; Fig. 5; Supplement Table S3b). Lower montane and upper montane forest organic layer soils showed the highest flux $\left(472 \pm 139\right.$ and $576 \pm 117 \mathrm{ng} \mathrm{N}_{2}$ ${ }^{15} \mathrm{Ng}^{-1} \mathrm{~d}^{-1}$, respectively), while all other habitats showed similar flux rates $\left(105 \pm 19 \mathrm{ng} \mathrm{N}_{2}{ }^{15} \mathrm{Ng}^{-1} \mathrm{~d}^{-1}\right.$ ) (Fisher's LSD, $P<0.05$; Fig. 5).

\subsection{3 $\quad \mathrm{N}_{2} \mathrm{O}$ yield}

For the $\mathrm{N}_{2} \mathrm{O}$ yield, we used a full factorial ANOVA on BoxCox transformed data with habitat, $\mathrm{N}$ addition level, incubation phase (i.e. early versus late), and all their interaction terms as independent variables. We found that none of these factors predicted $\mathrm{N}_{2} \mathrm{O}$ yield (ANOVA, $F_{29,149}=0.75$, $P>0.82$; Supplement Table S3c). The overall mean $\mathrm{N}_{2} \mathrm{O}$ yield for the pooled dataset was $0.53 \pm 0.04$.

\section{Discussion}

\subsection{Effects of seasonality and soil moisture on $\mathrm{N}_{2} \mathrm{O}$ flux}

Nitrous oxide flux in the Kosñipata Valley showed weak seasonality, with greater $\mathrm{N}_{2} \mathrm{O}$ flux during the dry season compared to the wet season. This regional trend was consistent with results from our prior study, and was principally driven 


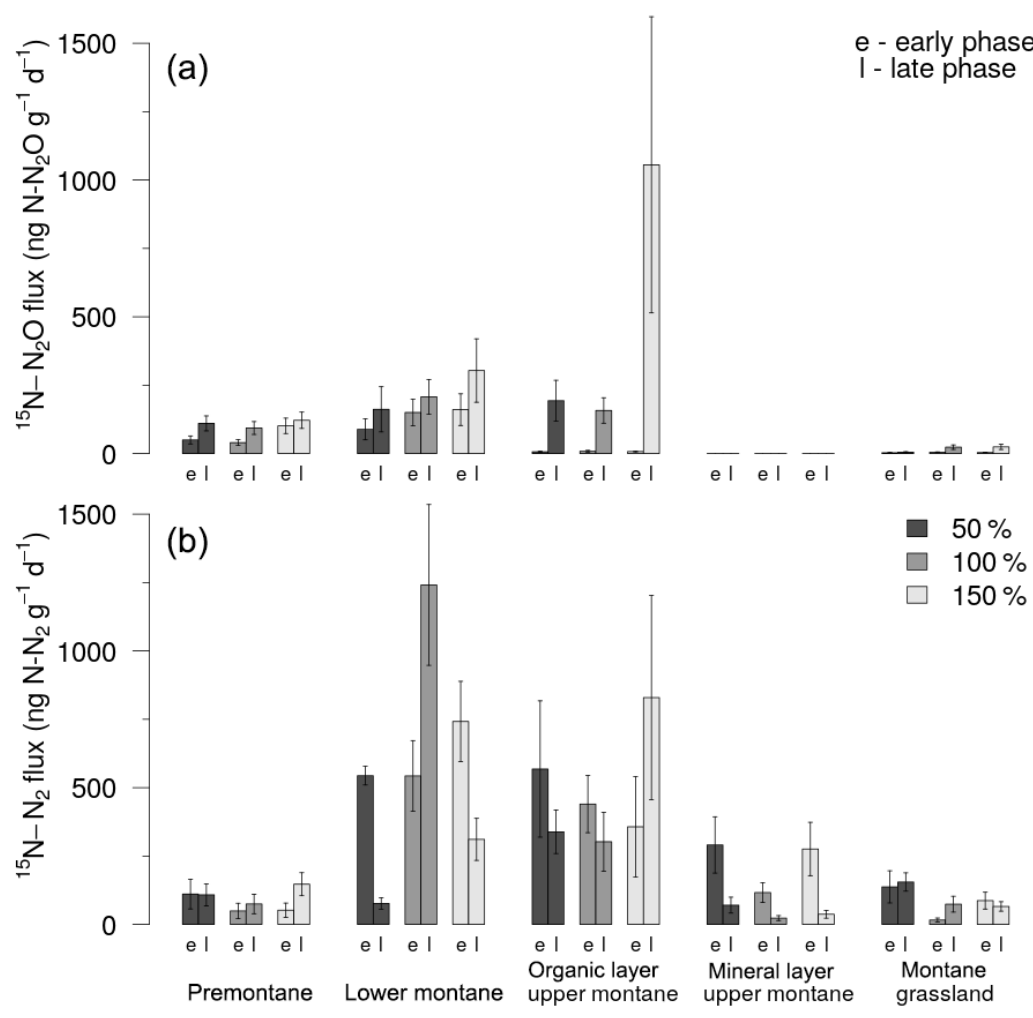

Figure 5. (a) ${ }^{15} \mathrm{~N}-\mathrm{N}_{2} \mathrm{O}$ flux and (b) ${ }^{15} \mathrm{~N}-\mathrm{N}_{2}$ flux during the early $(\leq 24 \mathrm{~h})$ and late $\left(>24 \mathrm{~h}\right.$ ) incubation phases of the $\mathrm{NO}_{3}^{-}$addition experiment. Results from the $+50 \% \mathrm{NO}_{3}^{-}$addition are shown in dark grey, while data from the +100 and $+150 \%$ treatments are shown in mid grey and light grey, respectively. The bar charts show means and standard errors.

by strong seasonality in $\mathrm{N}_{2} \mathrm{O}$ flux from lower montane forest (Teh et al., 2014). In contrast, other habitats showed little or no seasonal variation in $\mathrm{N}_{2} \mathrm{O}$ flux. This weak seasonality in $\mathrm{N}_{2} \mathrm{O}$ flux across the Kosñipata Valley probably stems from relatively modest variation in environmental variables among seasons (Table 3), in accordance with observations from elsewhere in the Andes (Baldos et al., 2015; Müller et al., 2015; Wolf et al., 2011). For example, while soil moisture (i.e. WFPS) varied significantly between seasons in the dataset as a whole, the absolute difference in WFPS between dry season and wet season were relatively small (i.e. $7.4 \%$ ). Indeed, some habitats showed much smaller variations in soil moisture, such as premontane forest and montane grassland that showed no significant seasonal variation in WFPS whatsoever (Table 3).

One critical factor contributing to these weak seasonal trends in $\mathrm{N}_{2} \mathrm{O}$ flux is the atypical response of $\mathrm{N}_{2} \mathrm{O}$ flux to changes in soil moisture. Nitrous oxide flux showed a weak but negative correlation with WFPS in the field dataset $\left(r^{2}=\right.$ $0.01, P<0.06$ for the pooled dataset), rather than following a curvilinear pattern predicted by denitrification theory (Firestone and Davidson, 1989; Firestone et al., 1980; Weier et al., 1993; Davidson, 1991). Likewise, in our soil moisture manipulation experiments, nitrification made a minor contribution to $\mathrm{N}_{2} \mathrm{O}$ production, irrespective of soil moisture content
(Supplement Fig. S1). This finding is contrary to theoretical predictions of $\mathrm{N}_{2} \mathrm{O}$ production by ammonia-oxidizing bacteria (AOB), where $\mathrm{N}_{2} \mathrm{O}$ production from ammonia oxidation is thought to make an important contribution to $\mathrm{N}_{2} \mathrm{O}$ flux at lower soil moisture contents (i.e. 30-60\% WFPS) (Firestone and Davidson, 1989; Firestone et al., 1980; Weier et al., 1993; Davidson, 1991). At higher soil moisture contents (i.e. $>60 \%$ WFPS), $\mathrm{N}_{2} \mathrm{O}$ flux showed a non-linear response to increasing WFPS, with two distinct peaks in $\mathrm{N}_{2} \mathrm{O}$ flux at 90 and $50 \%$ WFPS (Fig. 4). Collectively, these findings suggest that the role of soil moisture in regulating $\mathrm{N}_{2} \mathrm{O}$ flux is more complex than predicted by existing theory, falsifying our first two hypotheses.

What could explain these unexpected trends? We believe that these patterns occurred due to the complex interplay between environmental conditions and the microbial processes that produce $\mathrm{N}_{2} \mathrm{O}$ in soil (i.e. ammonia oxidation by archaea, ammonia oxidation by bacteria, denitrification, dissimilatory nitrate reduction to ammonium). We suspect that the action of lesser-known microbial processes, such as oxidation of ammonia by archaea and dissimilatory nitrate reduction to ammonium (DNRA), may explain the divergence from theoretical norms. Our expectations of how $\mathrm{N}_{2} \mathrm{O}$ production should respond to variations in soil moisture are predicated on the assumption that $\mathrm{N}_{2} \mathrm{O}$ is produced almost 
exclusively by AOB and denitrifying bacteria, with the former operating at lower soil moisture content (i.e. 30-60\% WFPS) and the latter at higher soil moisture content (i.e. $>60 \%$ WFPS) (Firestone and Davidson, 1989; Firestone et al., 1980; Weier et al., 1993; Davidson, 1991). More recent advances in soil $\mathrm{N}$ research, however, have highlighted the importance of other microbial taxa or processes, not previously considered in conceptual or process-based models. For example, recent work in acidic soils have demonstrated that ammonia oxidizing archaea (AOA) play a more important role than AOB in ammonia oxidation, but produce significantly less $\mathrm{N}_{2} \mathrm{O}$ due to differences in metabolism (Hink et al., 2016; Prosser and Nicol, 2008). Likewise, under higher soil moisture conditions ( $>60 \%$ WFPS), DNRA - a process that produces substantially less $\mathrm{N}_{2} \mathrm{O}$ than denitrification and which also competes for $\mathrm{NO}_{3}^{-}$with denitrification - can dominate nitrate reduction, depending on redox conditions and the relative availability of labile $\mathrm{C}$ and $\mathrm{N}$ (Morley and Baggs, 2010; Pett-Ridge and Firestone, 2005; Silver et al., 2001; Baldos et al., 2015; Müller et al., 2015). Thus, given the low pH of the soils in Kosñipata Valley (Table 1), it is likely that AOA dominate ammonia oxidation at lower levels of soil moisture, explaining the negligible amounts of $\mathrm{N}_{2} \mathrm{O}$ produced from nitrification in the 30 and $50 \%$ WFPS treatments. As soils become wetter, the non-linear response of $\mathrm{N}_{2} \mathrm{O}$ flux to increasing soil moisture may reflect competition for substrates (e.g. $\mathrm{NO}_{3}^{-}$, reducing equivalents) between DNRA and denitrification (Morley and Baggs, 2010; Silver et al., 2001), or may indicate that DNRA is making a larger contribution to $\mathrm{N}_{2} \mathrm{O}$ flux than denitrification (Streminska et al., 2012).

These findings are important and noteworthy, given that climatically driven variations in soil moisture content are thought to be one of the dominant drivers for $\mathrm{N}_{2} \mathrm{O}$ flux in the seasonally dry tropics (Davidson, 1991; Firestone and Davidson, 1989; Groffman et al., 2009; Davidson and Verchot, 2000; Teh et al., 2014; van Lent et al., 2015; Werner et al., 2007). Moreover, similar results from comparable research sites in the Ecuadorian Andes lend credence to our claims (Baldos et al., 2015; Müller et al., 2015). For example, Müller et al. (2015) found that nitrification produced little or no $\mathrm{N}_{2} \mathrm{O}$ in acidic Ecuadorian soils, in agreement with findings from this study. Likewise, ${ }^{15} \mathrm{~N}$ isotope pool dilution experiments, in comparable habitats and elevations to our own, revealed that DNRA played a significant role in nitrate reduction, supporting the notion that DNRA may represent a substantial sink for $\mathrm{NO}_{3}^{-}$in Peruvian soils (Baldos et al., 2015; Müller et al., 2015). Existing process-based models, which are used to construct bottom-up emissions inventories for the tropics (Werner et al., 2007), often assume that $\mathrm{N}_{2} \mathrm{O}$ is derived primarily from $\mathrm{AOB}$ and denitrification, with moisture response curves based on existing theoretical relationships (Li et al., 2000; Werner et al., 2007; Smith et al., 2007). However, if these more "normative" soil moisture response curves are inapplicable to montane tropical ecosystems, due to the activity of AOA and DNRA, then a re-conceptualization of the soil moisture- $\mathrm{N}_{2} \mathrm{O}$ flux relationship may be required. Moreover, if weak seasonality or aseasonality in $\mathrm{N}_{2} \mathrm{O}$ flux is the norm in Andean ecosystems (Müller et al., 2015; Wolf et al., 2011), then this finding may have wider implications for understanding spatial or temporal trends in regional atmospheric budgets (Kort et al., 2011; Nevison et al., 2004, 2007; Saikawa et al., 2014).

\subsection{Role of substrate limitation in regulating $\mathrm{N}_{2} \mathrm{O}$ flux}

In accordance with our earlier work (Teh et al., 2014) and research conducted in analogous ecosystems in Ecuador (Baldos et al., 2015; Müller et al., 2015; Wolf et al., 2011), we found strong evidence that $\mathrm{N}_{2} \mathrm{O}$ flux was constrained by the availability of $\mathrm{NO}_{3}^{-}$, partially supporting our third hypothesis. In contrast, $\mathrm{N}_{2} \mathrm{O}$ flux was unresponsive to short-term changes in labile organic matter (i.e. leaf litter-fall) inputs, indicating that $\mathrm{N}_{2} \mathrm{O}$ flux and nitrate reduction were not $\mathrm{Clim}$ ited. This latter result is significant for modelling and extrapolating $\mathrm{N}_{2} \mathrm{O}$ flux from these habitats, because many processbased models assume that $\mathrm{N}$ cycling and turnover of labile organic matter are intimately linked through processes such as litter production and decomposition (Li et al., 2000; Werner et al., 2007; Smith et al., 2007).

Evidence for $\mathrm{NO}_{3}^{-}$limitation of $\mathrm{N}_{2} \mathrm{O}$ flux comes from both our field and laboratory data, and suggests that "habitat" may be a good proxy for $\mathrm{NO}_{3}^{-}$availability and $\mathrm{N}_{2} \mathrm{O}$ flux because these two variables co-vary with habitat. For example, we observed an inverse trend in field $\mathrm{N}_{2} \mathrm{O}$ flux, with premontane forest showing significantly greater flux than the other habitats' elevation (Table 3, Fig. 2a). This inverse trend was also reflected in the resin-extractable $\mathrm{NO}_{3}^{-}$flux measured in the field and the ${ }^{15} \mathrm{~N}-\mathrm{N}_{2} \mathrm{O}$ flux measured in the $\mathrm{NO}_{3}^{-}$addition experiment in the laboratory (Figs. 2c, 5a). Furthermore, the behaviour of the ${ }^{15} \mathrm{~N}-\mathrm{NO}_{3}^{-}$amended soils during the early $(\leq 24 \mathrm{~h})$ and late $(>24 \mathrm{~h})$ phases of the incubation experiment suggests that soils from more $\mathrm{N}$-poor habitats (i.e. those with lower rates of resin-extractable $\mathrm{NO}_{3}^{-}$flux; Table 3, Fig. 2c) showed a greater proportional increase in ${ }^{15} \mathrm{~N}-\mathrm{N}_{2} \mathrm{O}$ flux following $\mathrm{NO}_{3}^{-}$addition than $\mathrm{N}$-rich habitats (i.e. those with higher rates of resin-extractable $\mathrm{NO}_{3}^{-}$flux; Table 3, Fig. 2c), suggesting that ${ }^{15} \mathrm{~N}-\mathrm{N}_{2} \mathrm{O}$ flux was more $\mathrm{NO}_{3}^{-}$limited in $\mathrm{N}$-poor soils (Fig. 5). Soils from the upper montane forest organic layer, montane grasslands, and upper montane forest mineral layer showed the lowest ${ }^{15} \mathrm{~N}-\mathrm{N}_{2} \mathrm{O}$ flux during the early phase of soil incubation, but the greatest proportional increase in flux during the late phase of soil incubation, rising by factors of 59,5 , and 2 , respectively. In contrast, lower montane and premontane forest soils showed the smallest proportional increase in the late phase of soil incubation (i.e. 1.7 times increase). Last, the relatively low $\mathrm{N}_{2} \mathrm{O}$ yield observed in our soil moisture manipulations is thought to be broadly indicative of low $\mathrm{NO}_{3}^{-}$conditions (i.e. $<0.42$ for forested habitats; Table 4), further supporting the 
notion that $\mathrm{N}_{2} \mathrm{O}$ flux in this region is generally $\mathrm{NO}_{3}^{-}$limited (Schlesinger, 2009; Fang et al., 2015; Weier et al., 1993).

Interestingly, increasing $\mathrm{NO}_{3}^{-}$availability per se did not stimulate ${ }^{15} \mathrm{~N}-\mathrm{N}_{2} \mathrm{O}$ flux and ${ }^{15} \mathrm{~N}-\mathrm{N}_{2}$ flux, or alter $\mathrm{N}_{2} \mathrm{O}$ yield during the early phase $(<24 \mathrm{~h})$ of the $\mathrm{NO}_{3}^{-}$addition experiment, even though we did observe that ${ }^{15} \mathrm{~N}-\mathrm{N}_{2} \mathrm{O}$ flux increased during the late phase $(>24 \mathrm{~h}$ ) of the experiments (please see Fig. 5 and the discussion in the preceding paragraph). Rather, ANCOVA suggests that ${ }^{15} \mathrm{~N}-\mathrm{N}_{2} \mathrm{O}$ and ${ }^{15} \mathrm{~N}-$ $\mathrm{N}_{2}$ fluxes in the early phase of the $\mathrm{NO}_{3}^{-}$addition experiment were better predicted by habitat, i.e. that soil provenance was a better predictor of ${ }^{15} \mathrm{~N}-\mathrm{N}_{2} \mathrm{O}$ flux than $\mathrm{N}$ treatment. $\mathrm{N}_{2} \mathrm{O}$ yield, normally a sensitive indicator of $\mathrm{NO}_{3}^{-}$availability (Blackmer and Bremner, 1978; Weier et al., 1993; Parton et al., 1996), also showed no immediate response to the amount of ${ }^{15} \mathrm{~N}-\mathrm{NO}_{3}^{-}$added, nor any of the other explanatory variables. One explanation for this, consistent with the notion that $\mathrm{N}_{2} \mathrm{O}$ flux is $\mathrm{NO}_{3}^{-}$limited, is that nitratereducing microbes in these soils may have a relatively low half-saturation constant $\left(K_{\mathrm{m}}\right)$ for $\mathrm{NO}_{3}^{-}$, and effectively utilize $\mathrm{NO}_{3}^{-}$whenever concentrations increase above baseline (i.e. non-limiting) levels (Holtan-Hartwig et al., 2000). As a consequence, we may be unable to differentiate among $\mathrm{NO}_{3}^{-}$ treatments in the early phase of the experiment, because the amount of $\mathrm{NO}_{3}^{-}$added exceeded the $K_{\mathrm{m}}$ for these soils. This finding is also in agreement with results from long-term $\mathrm{N}$ fertilization studies, which suggest that substantive shifts in $\mathrm{N}_{2} \mathrm{O}$ flux are only likely to occur after prolonged exposure to high levels of $\mathrm{N}$ (i.e. $>1$ year), rather than due to transient fluctuations in $\mathrm{N}$ availability (Baldos et al., 2015; Corre et al., 2010; Müller et al., 2015; Hall and Matson, 1999; Koehler et al., 2012).

\subsection{Implications for annual atmospheric budgets and gaseous $\mathbf{N}$ loss}

Montane ecosystems in the Kosñipata Valley were net sources of atmospheric $\mathrm{N}_{2} \mathrm{O}$, affirming our prior results (Teh et al., 2014). The flux for this multi-annual dataset was comparable to the preliminary values reported in our earlier publication, with an unweighted mean flux of $0.27 \pm 0.07 \mathrm{mg} \mathrm{N}-$ $\mathrm{N}_{2} \mathrm{O} \mathrm{m}^{-2} \mathrm{~d}^{-1}$ observed over a 30-month period compared to $0.22 \pm 0.12 \mathrm{mg} \mathrm{N}-\mathrm{N}_{2} \mathrm{O} \mathrm{m}^{-2} \mathrm{~d}^{-1}$ recorded over a 13 month period (Teh et al., 2014). These values correspond to unweighted mean annual fluxes of $0.99 \pm 0.26 \mathrm{~kg} \mathrm{~N}_{2} \mathrm{O}-$ $\mathrm{Nha}^{-1} \mathrm{yr}^{-1}$ and $0.80 \pm 0.44 \mathrm{~kg} \mathrm{~N}_{2} \mathrm{O}-\mathrm{Nha}^{-1} \mathrm{yr}^{-1}$, respectively. However, in order to derive more accurate estimates of the annual contribution of the Kosñipata Valley to the regional atmospheric budget of $\mathrm{N}_{2} \mathrm{O}$, it is necessary to account for differences in land area for different habitats and variation in the magnitude of $\mathrm{N}_{2} \mathrm{O}$ flux between seasons. Thus, we conducted a simple weighted upscaling exercise to more fully account for these two sources of variation (Table 4). Using the $\mathrm{N}_{2} \mathrm{O}$ yield data from the laboratory tracer experiments, we also estimated the annual $\mathrm{N}_{2}$ flux and total gaseous

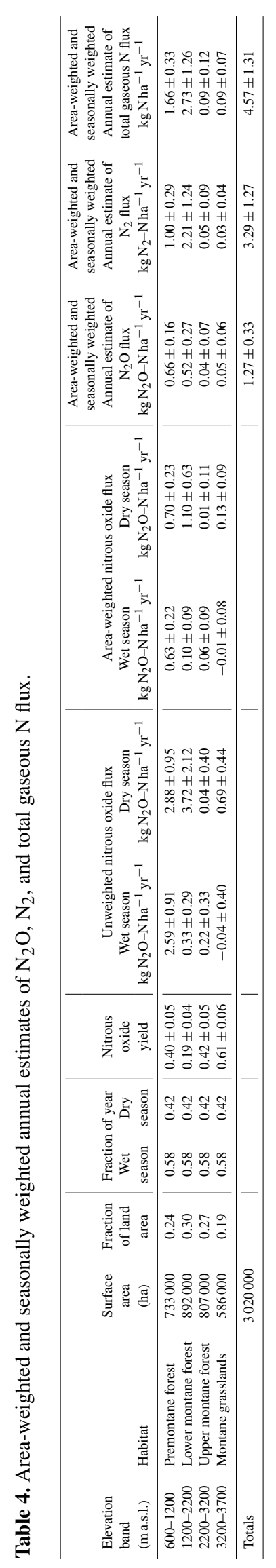

Biogeosciences, 14, 5077-5097, 2017 
$\mathrm{N}$ flux, in order to compare rates of gaseous $\mathrm{N}$ export from this region with other forested ecosystems (Fang et al., 2015; Russell and Raich, 2012; Tietema and Verstraten, 1991; Bai et al., 2012) (Table 4). We fully acknowledge that this simple approach is not as robust as bottom-up, process-based emissions inventories (Werner et al., 2007). Even so, we believe it is still useful for providing first-order approximations of annual $\mathrm{N}_{2} \mathrm{O}, \mathrm{N}_{2}$, and total gaseous $\mathrm{N}$ flux.

To briefly summarize our methodology, our first step was to use published surface area estimates for the different habitats in the Kosñipata Valley to derive areal fractions for each habitat (Feeley and Silman, 2010) (Table 4). Next, we multiplied the unweighted seasonal mean flux by the areal fraction for each habitat to derive area-weighted seasonal flux estimates (Table 4). We subsequently multiplied the areaweighted seasonal flux by the fraction of the year accounted for by either season, in order to produce an area-weighted and seasonally weighted annual flux estimate for each habitat (Table 4). The final step of this process was to sum the area-weighted and seasonally weighted flux estimates for each habitat, to drive an overall weighted flux estimate for the Kosñipata Valley as a whole (Table 4). Weighted annual estimates of $\mathrm{N}_{2}$ flux were calculated using the $\mathrm{N}_{2} \mathrm{O}$ yield values for each habitat as determined in our soil moisture manipulation experiment (Table 4). We elected to use mean $\mathrm{N}_{2} \mathrm{O}$ yields for each habitat, rather than estimating $\mathrm{N}_{2} \mathrm{O}$ yield based on soil moisture content, because ANCOVA indicated that habitat was a better predictor of $\mathrm{N}_{2} \mathrm{O}$ yield than soil moisture, explaining a substantially greater proportion of the variance (i.e. $10 \%$ versus only $1 \%$ of the variance; see Supplement Table S2c). Total gaseous $\mathrm{N}$ export was estimate by calculating the sum of annual $\mathrm{N}_{2} \mathrm{O}$ and $\mathrm{N}_{2}$ flux. Errors for all the annual flux estimates (i.e. $\mathrm{N}_{2} \mathrm{O}, \mathrm{N}_{2}$, total gaseous $\mathrm{N}$ ) were propagated using standard error propagation techniques.

We determined that the Kosñipata Valley emitted approximately $1.27 \pm 0.33 \mathrm{~kg} \mathrm{~N}_{2} \mathrm{O}-\mathrm{N} \mathrm{ha}^{-1} \mathrm{yr}^{-1}, 3.29 \pm 1.27 \mathrm{~kg} \mathrm{~N}_{2}-$ $\mathrm{Nha}^{-1} \mathrm{yr}^{-1}$, and $4.57 \pm 1.31 \mathrm{~kg} \mathrm{Nha}^{-1} \mathrm{yr}^{-1}$. Annual $\mathrm{N}_{2} \mathrm{O}$ flux was broadly on par with our earlier estimates (i.e. $1.18 \pm 0.79 \mathrm{~kg} \mathrm{~N}_{2} \mathrm{O}-\mathrm{N} \mathrm{ha}^{-1} \mathrm{yr}^{-1}$ ) (Teh et al., 2014). This estimated annual rate of flux exceeds the value for montane tropical montane forests calculated by Werner et al. (2007) using a bottom-up process model (i.e. 0.5 to $1 \mathrm{~kg} \mathrm{~N}_{2} \mathrm{O}-$ $\mathrm{Nha}^{-1} \mathrm{yr}^{-1}$ ), but falls within the range predicted for humid tropical forest soils more generally (i.e. approximately $1-4 \mathrm{~kg} \mathrm{~N}_{2} \mathrm{O}-\mathrm{N} \mathrm{ha}^{-1} \mathrm{yr}^{-1}$ ) (van Lent et al., 2015; Werner et al., 2007). Annual $\mathrm{N}_{2}$ flux and total gaseous $\mathrm{N}$ flux are at the lower end of the range reported in comparable studies from other ecosystems (e.g. Fang et al., 2015 reported annual gaseous losses of 5.6-30.1 $\mathrm{kg} \mathrm{N} \mathrm{ha}^{-1} \mathrm{yr}^{-1}$ sampling across a broad range of temperate and tropical ecosystems) (Fang et al., 2015; Russell and Raich, 2012; Tietema and Verstraten, 1991; Bai et al., 2012), further supporting claims that Andean ecosystems are relatively $\mathrm{N}$ limited, and may cycle $\mathrm{N}$ more conservatively than lowland forests (Baldos et al.,
2015; Müller et al., 2015; Wolf et al., 2011; Nottingham et al., 2015)

\section{Conclusions}

Process-based studies of $\mathrm{N}_{2} \mathrm{O}$ flux from montane tropical ecosystems in the southern Peruvian Andes affirms prior research suggesting that these ecosystems are potentially important regional sources of $\mathrm{N}_{2} \mathrm{O}$ (Teh et al., 2014). Simple weighted upscaling suggests that annual $\mathrm{N}_{2} \mathrm{O}$ flux from the Kosñipata Valley is of the order of $1.27 \pm 0.33 \mathrm{~kg} \mathrm{~N}_{2} \mathrm{O}-$ $\mathrm{Nha}^{-1}$. Habitat - a proxy for $\mathrm{NO}_{3}^{-}$availability under field conditions - was the best predictor for $\mathrm{N}_{2} \mathrm{O}$ flux, with more $\mathrm{N}$-rich habitats (i.e. premontane forest) showing significantly higher $\mathrm{N}_{2} \mathrm{O}$ flux than habitats with lower $\mathrm{N}$ availability (i.e. upper montane forest, montane grassland). Nitrous oxide flux originated primarily from nitrate reduction rather than from nitrification, probably due to low $\mathrm{pH}$ soil conditions which may have inhibited the activity of AOB. Contrary to our prior research, we found only weak evidence for seasonal trends in field $\mathrm{N}_{2} \mathrm{O}$ flux, with the exception of lower montane forest, which showed significantly higher $\mathrm{N}_{2} \mathrm{O}$ flux during the dry season compared to the wet season. Weak seasonal trends in field $\mathrm{N}_{2} \mathrm{O}$ flux among the other montane habitats probably stems from relatively modest seasonal variation in key environmental drivers (e.g. temperature, WFPS, $\mathrm{NO}_{3}^{-}$), combined with a soil moisture response that was complex and non-linear. Nitrous oxide flux was significantly influenced by soil moisture content, but the trends in $\mathrm{N}_{2} \mathrm{O}$ production and flux diverged from theoretical norms. For example, we saw little evidence of $\mathrm{N}_{2} \mathrm{O}$ production from ammonia oxidation, even though the field measurements (i.e. resin bags) indicate that nitrification occurs. This may be due to the predominance of AOA, which produce significantly less $\mathrm{N}_{2} \mathrm{O}$ than AOB, under the acidic conditions common in Andean soils. At higher soil moisture levels, $\mathrm{N}_{2} \mathrm{O}$ flux increased nonlinearly with WFPS, with peaks in $\mathrm{N}_{2} \mathrm{O}$ flux at 90 and $50 \%$ WFPS. These results suggest that the effects of water on $\mathrm{N}_{2} \mathrm{O}$ flux are complicated by other factors, such as competition for substrates among different nitrate-reducing processes, or shifts in the amount of $\mathrm{N}_{2} \mathrm{O}$ derived from denitrification or DNRA. Field data and substrate manipulation experiments indicated that $\mathrm{N}_{2} \mathrm{O}$ flux was strongly limited by $\mathrm{NO}_{3}^{-}$, but unconstrained by the input rate of labile organic matter (i.e. leaf litter). Nitrous oxide flux was relatively insensitive to short-term variations in $\mathrm{NO}_{3}^{-}$, and was better predicted by longer-term, time-averaged variations in $\mathrm{NO}_{3}^{-}$availability.

Data availability. Data for this publication are publicly available from the UK Natural Environment Research Council (NERC) Centre for Environmental Data Analysis (CEDA), at the following URL: http://catalogue.ceda.ac.uk/uuid/ 93fdb48b713b4dbc93a28d695771312d (Diem et al., 2016). 


\section{The Supplement related to this article is available online at https://doi.org/10.5194/bg-14-5077-2017-supplement.}

Author contributions. TD designed the field and laboratory experiments, collected the field data, conducted the laboratory experiments, processed the samples, analysed the data, and contributed to the preparation of the manuscript. NJM contributed to the design of the laboratory experiments, assisted in the sample analysis, assisted in the analysis of the laboratory data, and contributed to the preparation of the manuscript. AJCQ and LPHQ assisted in the collection of the field data and processing of the field samples. EMB, PM, MR, and PS contributed to the experimental design and the preparation of the manuscript. YAT directed the research, contributed to the design of the experiments, assisted in the analysis of the field and laboratory data, and took the principal role in preparing the manuscript.

Competing interests. The authors declare that they have no conflict of interest.

Acknowledgements. The authors would like to acknowledge the agencies that funded this research; the UK Natural Environment Research Council (NERC; joint grant references NE/H006583, NE/H007849, and NE/H006753). Patrick Meir was supported by an Australian Research Council Fellowship (FT110100457). Javier Eduardo Silva Espejo, Walter Huaraca Huasco, and the ABIDA NGO provided critical fieldwork and logistical support. Angus Calder (University of St Andrews) and Vicky Munro (University of Aberdeen) provided invaluable laboratory support. Thanks to Adrian Tejedor from the Amazon Conservation Association, who provided assistance with site access and site selection at Hacienda Villa Carmen. This publication is a contribution from the Scottish Alliance for Geoscience, Environment and Society (http://www.sages.ac.uk).

Edited by: Fortunat Joos

Reviewed by: four anonymous referees

\section{References}

Baggs, E. M., Richter, M., Hartwig, U. A., and Cadisch, G.: Nitrous oxide emissions from grass swards during the eighth year of elevated atmospheric $\mathrm{pCO}_{2}$ (Swiss FACE), Glob. Change Biol., 9, 1214-1222, 2003.

Bai, E., Houlton, B. Z., and Wang, Y. P.: Isotopic identification of nitrogen hotspots across natural terrestrial ecosystems, Biogeosciences, 9, 3287-3304, https://doi.org/10.5194/bg-9-32872012, 2012.

Baldos, A. P., Corre, M. D., and Veldkamp, E.: Response of N cycling to nutrient inputs in forest soils across a 1000-3000 m elevation gradient in the Ecuadorian Andes, Ecology, 96, 749-761, https://doi.org/10.1890/14-0295.1, 2015.

Bateman, E. J. and Baggs, E. M.: Contributions of nitrification and denitrification to $\mathrm{N}_{2} \mathrm{O}$ emissions from soils at dif- ferent water-filled pore space, Biol. Fert. Soils, 41, 379-388, https://doi.org/10.1007/s00374-005-0858-3, 2005.

Belyea, L. R. and Baird, A. J.: Beyond "The limits to peat bog growth": Cross-scale feedback in peatland development, Ecol. Monogr., 76, 299-322, 2006.

Blackmer, A. M. and Bremner, J. M.: Inhibitory effect of nitrate on reduction of $\mathrm{N}_{2} \mathrm{O}$ to $\mathrm{N}_{2}$ by soil microorganisms, Soil Biol. Biochem., 10, 187-191, https://doi.org/10.1016/00380717(78)90095-0, 1978.

Breuer, L., Papen, H., and Butterbach-Bahl, K.: $\mathrm{N}_{2} \mathrm{O}$ emission from tropical forest soils of Australia, J. Geophys. Res.-Atmos., 105, 26353-26367, https://doi.org/10.1029/2000jd900424, 2000.

Corre, M. D., Veldkamp, E., Arnold, J., and Wright, S. J.: Impact of elevated $\mathrm{N}$ input on soil $\mathrm{N}$ cycling and losses in old-growth lowland and montane forests in Panama, Ecology, 91, 1715-1729, https://doi.org/10.1890/09-0274.1, 2010.

Davidson, E. A.: Fluxes of nitrous oxide and nitric oxide from terrestrial ecosystems, in: Microbial production and consumption of greenhouse gases: methane, nitrogen oxides, and halomethanes, edited by: Rogers, J. E. and Whitman, W. B., American Society for Microbiology, Washington DC, 219-236, 1991.

Davidson, E. A. and Verchot, L. V.: Testing the Hole-in-the-Pipe Model of nitric and nitrous oxide emissions from soils using the TRAGNET Database, Global Biogeochem. Cy., 14, 1035-1043, https://doi.org/10.1029/1999GB001223, 2000.

Diem, T., Jones, S. P., Baggs, E., Smith, P., Meir, P., and Teh, Y. A.: NERC Project: Are tropical uplands regional hotspots for methane and nitrous oxide?: in-situ ground based atmospheric flux measurements and model output. Centre for Environmental Data Analysis, available at: http://catalogue.ceda.ac.uk/uuid/ 93fdb48b713b4dbc93a28d695771312d (last access: 3 November 2017), 2016.

Eva, H. D., Belward, A. S., De Miranda, E. E., Di Bella, C. M., Gond, V., Huber, O., Jones, S., Sgrenzaroli, M., and Fritz, S.: A land cover map of South America, Glob. Change Biol., 10, 731744, https://doi.org/10.1111/j.1529-8817.2003.00774.x, 2004.

Fang, Y., Koba, K., Makabe, A., Takahashi, C., Zhu, W., Hayashi, T., Hokari, A. A., Urakawa, R., Bai, E., Houlton, B. Z., Xi, D., Zhang, S., Matsushita, K., Tu, Y., Liu, D., Zhu, F., Wang, Z., Zhou, G., Chen, D., Makita, T., Toda, H., Liu, X., Chen, Q., Zhang, D., Li, Y., and Yoh, M.: Microbial denitrification dominates nitrate losses from forest ecosystems, P. Natl. Acad. Sci. USA, 112, 1470-1474, https://doi.org/10.1073/pnas.1416776112, 2015.

Feeley, K. J. and Silman, M. R.: Land-use and climate change effects on population size and extinction risk of Andean plants, Glob. Change Biol., 16, 3215-3222, https://doi.org/10.1111/j.1365-2486.2010.02197.x, 2010.

Firestone, M. K. and Davidson, E. A.: Microbiological basis of $\mathrm{NO}$ and $\mathrm{N}_{2} \mathrm{O}$ production and consumption in soil, in: Exchange of Trace Gases Between Terrestrial Ecosystems and the Atmosphere, edited by: Andrae, M. O. and Schimel, D. S., John Wiley and Sons Ltd., New York, 7-21, 1989.

Firestone, M. K., Firestone, R. B., and Tiedge, J. M.: Nitrous oxide from soil denitrification: Factors controlling its biological production, Science, 208, 749-751, 1980.

Girardin, C. A. J., Malhi, Y., Aragão, L. E. O. C., Mamani, M., Huaraca Huasco, W., Durand, L., Feeley, K. J., Rapp, J., SilvaEspejo, J. E., Silman, M., Salinas, N., and Whittaker, R. J.: Net 
primary productivity allocation and cycling of carbon along a tropical forest elevational transect in the Peruvian Andes, Glob. Change Biol., 16, 3176-3192, https://doi.org/10.1111/j.13652486.2010.02235.x, 2010.

Groffman, P. M., Butterbach-Bahl, K., Fulweiler, R. W., Gold, A. J., Morse, J. L., Stander, E. K., Tague, C., Tonitto, C., and Vidon, P.: Challenges to incorporating spatially and temporally explicit phenomena (hotspots and hot moments) in denitrification models, Biogeochemistry, 93, 49-77, https://doi.org/10.1007/s10533-008-9277-5, 2009.

Hall, S. J. and Matson, P. A.: Nitrogen oxide emissions after nitrogen additions in tropical forests, Nature, 400, 152-155, 1999.

Hink, L., Nicol, G. W., and Prosser, J. I.: Archaea produce lower yields of $\mathrm{N}_{2} \mathrm{O}$ than bacteria during aerobic ammonia oxidation in soil, Environ. Microbiol., https://doi.org/10.1111/14622920.13282, online first, 2016.

Hirsch, A. I., Michalak, A. M., Bruhwiler, L. M., Peters, W., Dlugokencky, E. J., and Tans, P. P.: Inverse modeling estimates of the global nitrous oxide surface flux from 1998-2001, Global Biogeochem. Cy., 20, 1-17, Gb1008, https://doi.org/10.1029/2004gb002443, 2006.

Holtan-Hartwig, L., Dorsch, P., and Bakken, L. R.: Comparison of denitrifying communities in organic soils: kinetics of $\mathrm{NO}_{3}^{-}$and $\mathrm{N}_{2} \mathrm{O}$ reduction, Soil Biol. Biochem., 32, 833-843, https://doi.org/10.1016/s0038-0717(99)00213-8, 2000.

Huang, J., Golombek, A., Prinn, R., Weiss, R., Fraser, P., Simmonds, P., Dlugokencky, E. J., Hall, B., Elkins, J., Steele, P., Langenfelds, R., Krummel, P., Dutton, G., and Porter, L.: Estimation of regional emissions of nitrous oxide from 1997 to 2005 using multinetwork measurements, a chemical transport model, and an inverse method, J. Geophys. Res.-Atmos., 113, D17313, https://doi.org/10.1029/2007jd009381, 2008.

Jones, S. P., Diem, T., Huaraca Quispe, L. P., Cahuana, A. J., Reay, D. S., Meir, P., and Teh, Y. A.: Drivers of atmospheric methane uptake by montane forest soils in the southern Peruvian Andes, Biogeosciences, 13, 4151-4165, https://doi.org/10.5194/bg-134151-2016, 2016.

Koehler, B., Corre, M. D., Steger, K., Well, R., Zehe, E., Sueta, J. P., and Veldkamp, E.: An in-depth look into a tropical lowland forest soil: nitrogen-addition effects on the contents of $\mathrm{N}_{2} \mathrm{O}$, $\mathrm{CO}_{2}$ and $\mathrm{CH}_{4}$ and $\mathrm{N}_{2} \mathrm{O}$ isotopic signatures down to 2-m depth, Biogeochemistry, 111, 695-713, https://doi.org/10.1007/s10533012-9711-6, 2012.

Kort, E. A., Patra, P. K., Ishijima, K., Daube, B. C., Jimenez, R., Elkins, J., Hurst, D., Moore, F. L., Sweeney, C., and Wofsy, S. C.: Tropospheric distribution and variability of $\mathrm{N}_{2} \mathrm{O}$ : Evidence for strong tropical emissions, Geophys. Res. Lett., 38, 1-5, https://doi.org/10.1029/2011gl047612, 2011.

Li, C., Aber, J., Stange, F., Butterbach-Bahl, K., and Papen, H.: A process-oriented model of $\mathrm{N}_{2} \mathrm{O}$ and $\mathrm{NO}$ emissions from forest soils: 1. Model development, J. Geophys. Res.-Atmos., 105, 4369-4384, https://doi.org/10.1029/1999JD900949, 2000.

Limmer, A. W. and Steele, K. W.: Denitrification potentials: Measurement of seasonal variation using a short-term anaerobic incubation technique, Soil Biol. Biochem., 14, 179-184, https://doi.org/10.1016/0038-0717(82)90020-7, 1982.

Livingston, G. and Hutchinson, G.: Chapter 2: Enclosure-based measurement of trace gas exchange: applications and sources of error, in: Biogenic Trace Gases: Measuring Emissions from Soil and Water, edited by: Matson, P., Harriss, R. C., Blackwell Science Ltd, Cambridge, MA, USA, 14-51, 1995.

Malhi, Y., Silman, M., Salinas, N., Bush, M., Meir, P., and Saatchi, S.: Introduction: Elevation gradients in the tropics: laboratories for ecosystem ecology and global change research, Glob. Change Biol., 16, 3171-3175, https://doi.org/10.1111/j.13652486.2010.02323.x, 2010.

Morley, N. and Baggs, E. M.: Carbon and oxygen controls on $\mathrm{N}_{2} \mathrm{O}$ and $\mathrm{N}-2$ production during nitrate reduction, Soil Biol. Biochem., 42, 1864-1871, https://doi.org/10.1016/j.soilbio.2010.07.008, 2010.

Moser, G., Leuschner, C., Hertel, D., Graefe, S., Soethe, N., and Iost, S.: Elevation effects on the carbon budget of tropical mountain forests (S Ecuador): the role of the belowground compartment, Glob. Change Biol., 17, 2211-2226, https://doi.org/10.1111/j.1365-2486.2010.02367.x, 2011.

Müller, A. K., Matson, A. L., Corre, M. D., and Veldkamp, E.: Soil $\mathrm{N}_{2} \mathrm{O}$ fluxes along an elevation gradient of tropical montane forests under experimental nitrogen and phosphorus addition, Front. Earth Sci., 3, 1-12, https://doi.org/10.3389/feart.2015.00066, 2015.

Nevison, C. D., Lueker, T. J., and Weiss, R. F.: Quantifying the nitrous oxide source from coastal upwelling, Global Biogeochem. Cy., 18, Gb1018, https://doi.org/10.1029/2003gb002110, 2004.

Nevison, C. D., Mahowald, N. M., Weiss, R. F., and Prinn, R. G.: Interannual and seasonal variability in atmospheric $\mathrm{N}_{2} \mathrm{O}$, Global Biogeochem. Cy., 21, GB3017, https://doi.org/10.1029/2006GB002755, 2007.

Nottingham, A. T., Turner, B. L., Whitaker, J., Ostle, N. J., McNamara, N. P., Bardgett, R. D., Salinas, N., and Meir, P.: Soil microbial nutrient constraints along a tropical forest elevation gradient: a belowground test of a biogeochemical paradigm, Biogeosciences, 12, 6071-6083, https://doi.org/10.5194/bg-126071-2015, 2015.

Parton, W. J., Mosier, A. R., Ojima, D. S., Valentine, D. W., Schimel, D. S., Weier, K., and Kulmala, A. E.: Generalized model for $\mathrm{N}_{2}$ and $\mathrm{N}_{2} \mathrm{O}$ production from nitrification and denitrification, Global Biogeochem. Cy., 10, 401-412, https://doi.org/10.1029/96GB01455, 1996.

Pedersen, A. R., Petersen, S. O., and Schelde, K.: A comprehensive approach to soil-atmosphere trace-gas flux estimation with static chambers, Eur. J. Soil Sci., 61, 888-902, https://doi.org/10.1111/j.1365-2389.2010.01291.x, 2010.

Pett-Ridge, J. and Firestone, M. K.: Redox fluctuation structures microbial communities in a wet tropical soil, Appl. Environ. Microbiol., 71, 6998-7007, https://doi.org/10.1128/aem.71.11.69987007.2005, 2005.

Potter, C. S., Matson, P. A., Vitousek, P. M., and Davidson, E. A.: Process modeling of controls on nitrogen trace gas emissions from soils worldwide, J. Geophys. Res.-Atmos., 101, 13611377, https://doi.org/10.1029/95JD02028, 1996.

Prosser, J. I. and Nicol, G. W.: Relative contributions of archaea and bacteria to aerobic ammonia oxidation in the environment, Environ. Microbiol., 10, 2931-2941, https://doi.org/10.1111/j.14622920.2008.01775.x, 2008.

Pumpanen, J., Kolari, P., Ilvesniemi, H., Minkkinen, K., Vesala, T., Niinistö, S., Lohila, A., Larmola, T., Morero, M., Pihlatie, M., Janssens, I., Yuste, J. C., Grünzweig, J. M., Reth, S., Subke, J.A., Savage, K., Kutsch, W., Østreng, G., Ziegler, W., Anthoni, 
P., Lindroth, A., and Hari, P.: Comparison of different chamber techniques for measuring soil $\mathrm{CO}_{2}$ efflux, Agr. Forest Meteorol., 123, 159-176, https://doi.org/10.1016/j.agrformet.2003.12.001, 2004.

R Team, R. C.: A language and environment for statistical computing, R Foundation for Statistical Computing, Vienna, Austria, 2012.

Russell, A. E. and Raich, J. W.: Rapidly growing tropical trees mobilize remarkable amounts of nitrogen, in ways that differ surprisingly among species, P. Natl. Acad. Sci. USA, 109, 1039810402, https://doi.org/10.1073/pnas.1204157109, 2012.

Saikawa, E., Schlosser, C. A., and Prinn, R. G.: Global modeling of soil nitrous oxide emissions from natural processes, Global Biogeochem. Cy., 27, 972-989, https://doi.org/10.1002/gbc.20087, 2013.

Saikawa, E., Prinn, R. G., Dlugokencky, E., Ishijima, K., Dutton, G. S., Hall, B. D., Langenfelds, R., Tohjima, Y., Machida, T., Manizza, M., Rigby, M., O’Doherty, S., Patra, P. K., Harth, C. M., Weiss, R. F., Krummel, P. B., van der Schoot, M., Fraser, P. J., Steele, L. P., Aoki, S., Nakazawa, T., and Elkins, J. W.: Global and regional emissions estimates for $\mathrm{N}_{2} \mathrm{O}$, Atmos. Chem. Phys., 14, 4617-4641, https://doi.org/10.5194/acp14-4617-2014, 2014.

Schlesinger, W. H.: On the fate of anthropogenic nitrogen, P. Natl. Acad. Sci. USA, 106, 203-208, https://doi.org/10.1073/pnas.0810193105, 2009.

Silver, W. L., Herman, D. J., and Firestone, M. K. S.: Dissimilatory Nitrate Reduction to Ammonium in Upland Tropical Forest Soils, Ecology, 82, 2410-2416, 2001.

Smith, P., Smith, J. U., Flynn, H., Killham, K., Rangel-Castro, I., Foereid, B., Aitkenhead, M., Chapman, S., Towers, W., Bell, J., Lumsdon, D., Milne, R., Thomson, A., Simmons, I., Skiba, U., Reynolds, B., Evans, C., Frogbrook, Z., Bradley, I., Whitmore, A., and Falloon, P.: ECOSSE: Estimating Carbon in Organic Soils - Sequestration and Emissions, Final Report, Scottish Executive Environment and Rural Affairs Department Report, 166 pp., 2007.

Streminska, M. A., Felgate, H., Rowley, G., Richardson, D. J., and Baggs, E. M.: Nitrous oxide production in soil isolates of nitrate-ammonifying bacteria, Environ. Microbiol. Rep., 4, 6671, https://doi.org/10.1111/j.1758-2229.2011.00302.x, 2012.

Subler, S., Blair, J. M., and Edwards, C. A.: Using anionexchange membranes to measure soil nitrate availability and net nitrification, Soil Biol. Biochem., 27, 911-917, https://doi.org/10.1016/0038-0717(95)00008-3, 1995.

Teh, Y. A., Diem, T., Jones, S., Huaraca Quispe, L. P., Baggs, E., Morley, N., Richards, M., Smith, P., and Meir, P.: Methane and nitrous oxide fluxes across an elevation gradient in the tropical Peruvian Andes, Biogeosciences, 11, 2325-2339, https://doi.org/10.5194/bg-11-2325-2014, 2014.

Templer, P. H., Lovett, G. M., Weathers, K. C., Findlay, S. E., and Dawson, T. E.: Influence of tree species on forest nitrogen retention in the Catskill Mountains, New York, USA, Ecosystems, 8, 1-16, https://doi.org/10.1007/s10021-004-0230-8, 2005.

Tietema, A. and Verstraten, J. M.: Nitrogen cycling in an acid forest ecosystem in the Netherlands under increased atmospheric nitrogen input, Biogeochemistry, 15, 21-46, https://doi.org/10.1007/bf00002807, 1991. van Lent, J., Hergoualc'h, K., and Verchot, L. V.: Reviews and syntheses: Soil $\mathrm{N}_{2} \mathrm{O}$ and $\mathrm{NO}$ emissions from land use and land-use change in the tropics and subtropics: a meta-analysis, Biogeosciences, 12, 7299-7313, https://doi.org/10.5194/bg-127299-2015, 2015.

Varner, R. K., Keller, M., Robertson, J. R., Dias, J. D., Silva, H., Crill, P. M., McGroddy, M., and Silver, W. L.: Experimentally induced root mortality increased nitrous oxide emission from tropical forest soils, Geophys. Res. Lett., 30, 1-4, https://doi.org/10.1029/2002GL016164, 2003.

Veldkamp, E., Purbopuspito, J., Corre, M. D., Brumme, R., and Murdiyarso, D.: Land use change effects on trace gas fluxes in the forest margins of Central Sulawesi, Indonesia, J. Geophys. Res.Biogeo., 113, G02003, https://doi.org/10.1029/2007jg000522, 2008.

Weier, K. L., Doran, J. W., Power, J. F., and Walters, D. T.: Denitrification and the denitrogen nitrous oxide ratio as affected by soil water, available carbon, and nitrate, Soil Sci. Soc. Am. J., 57, 66-72, 1993.

Werner, C., Butterbach-Bahl, K., Haas, E., Hickler, T., and Kiese, R.: A global inventory of $\mathrm{N}_{2} \mathrm{O}$ emissions from tropical rainforest soils using a detailed biogeochemical model, Global Biogeochem. Cy., 21, Gb3010, https://doi.org/10.1029/2006gb002909, 2007.

Wolf, K., Veldkamp, E., Homeier, J., and Martinson, G. O.: Nitrogen availability links forest productivity, soil nitrous oxide and nitric oxide fluxes of a tropical montane forest in southern Ecuador, Global Biogeochem. Cy., 25, GB4009, https://doi.org/10.1029/2010GB003876, 2011.

Wolf, K., Flessa, H., and Veldkamp, E.: Atmospheric methane uptake by tropical montane forest soils and the contribution of organic layers, Biogeochemistry, 111, 469-483, https://doi.org/10.1007/s10533-011-9681-0, 2012.

Zimmermann, M., Meir, P., Bird, M., Malhi, Y., and Ccahuana, A.: Litter contribution to diurnal and annual soil respiration in a tropical montane cloud forest, Soil Biol. Biochem., 41, 1338-1340, 2009a.

Zimmermann, M., Meir, P., Bird, M. I., Malhi, Y., and Ccahuana, A. J. Q.: Climate dependence of heterotrophic soil respiration from a soil-translocation experiment along a $3000 \mathrm{~m}$ tropical forest altitudinal gradient, Eur. J. Soil Sci., 60, 895-906, https://doi.org/10.1111/j.1365-2389.2009.01175.x, 2009b.

Zimmermann, M., Leifeld, J., Conen, F., Bird, M. I., and Meir, P.: Can composition and physical protection of soil organic matter explain soil respiration temperature sensitivity?, Biogeochemistry, 107, 423-436, https://doi.org/10.1007/s10533-010-9562-y, 2012. 